\title{
Turkey's Evolving Trade Integration into Pan-European Markets •
}

\author{
By \\ Bartlomiej Kaminski ${ }^{*}$ and Francis $\mathrm{Ng}^{* *}$
}

\begin{abstract}
Summary: This is an empirical paper seeking to identify the mode of Turkey's integration into global markets in general and pan-European markets in particular as revealed in its trade performance. The analysis provides empirical support to the following observations. First, thanks to steady expansion of trade in goods and services since the mid-1980s, Turkey has become highly integrated into the world economy. Second, Turkey's export performance in 1996-2004 in EU markets bears strong similarities to the aggregate performance of new EU members from Central Europe (EU-8). Similarities include dynamics, similar factors responsible for the increased presence in EU markets, factor content and the role of 'producer-driven' network trade.

Turkey, together with Hungary, Czech Republic, Slovak Republic, Slovenia, Estonia and Poland, stands as one of the top performers in 'producer-driven' network trade indicating participation in a new global division of labor based on production fragmentation.

The available evidence suggests an economic success story in the making. Export expansion owes a lot to improved policy environment and domestic liberalization. It is rather telling that the recent expansion has coincided with the implementation of most of the provisions of EU-Turkey CU Agreement, the completion of the removal of tariffs on trade in industrial products among the pan-European parties to the Pan European Agreement Cumulation of the Rules of Origin and improved macroeconomic stability after the 2001 crisis.
\end{abstract}

World Bank Policy Research Working Paper 3908, May 2006

The Policy Research Working Paper Series disseminates the findings of work in progress to encourage the exchange of ideas about development issues. An objective of the series is to get the findings out quickly, even if the presentations are less than fully polished. The papers carry the names of the authors and should be cited accordingly. The findings, interpretations, and conclusions expressed in this paper are entirely those of the authors. They do not necessarily represent the view of the World Bank, its Executive Directors, or the countries they represent. Policy Research Working Papers are available online at http://econ.worldbank.org.

\footnotetext{
- Revised and updated version of a background report “Turkey's Surprising Mode of Trade Integration into Pan-European Markets” prepared for Turkey: A Country Economic Memorandum: Promoting Sustained Growth and Convergence with the European Union, ECA, World Bank, Washington, D.C. The authors are grateful to Subidey Togan and Aristomene Varoudakis for their comments on an earlier draft of this paper.

* / Department of Government, University of Maryland, College Park. E-mail: bkaminski@gvpt.umd.edu

** / Development Research Group -Trade, The World Bank, Washington, D.C. E-mail: fng@worldbank.org
} 


\section{Introduction}

The experience of countries that have successfully taken advantage of opportunities offered by global markets suggests that at least three critical elements have to be in place: macroeconomic stability, contestable and competitive domestic markets that are open to external competition and well-functioning backbone services. Macroeconomic instabilities destroy business activity. Contestable and competitive markets provide firms with access to cheap inputs and capital equipment that are well endowed in research and development, and force inefficient firms out of business. Backbone services (telecommunications, banking, insurance, transportation, business services, etc.) together with customs, related border clearance regulatory procedures, technical standards regulations and ports' efficiency shape the ease and speed with which goods and services move across national borders and, therefore, are crucial to trade in goods.

Historically, Turkey fails the macroeconomic test, as it has been "on a roller coaster of booms and busts for decades" (Barysch 2005), with the last crisis taking place in 2001. GDP fell 7 percent and inflation soared to 70 percent. Macroeconomic stability appears now to be under control, with inflation in the single-digit range and GDP strongly growing. As for the remaining two ingredients, the Customs Union Agreement with the EU has contributed immensely to the emergence of contestable domestic markets and the combination of measures supported by multilateral financial institutions has contributed to improved efficiency in services sectors (Hoekman and Subidey 2005).

Since all these measures are of relatively recent vintage, one would expect Turkey's performance to be poor in terms of its capacity to take advantage of opportunities offered, in particular, by policy-induced integration into the EU and pan-European markets for industrial products. But, contrary to expectations, this paper, which analyzes Turkey's dynamics and patterns of integration into global markets, provides empirical evidence that this has not been the case. While indeed imports fluctuated following the time pattern of GDP boosts and busts, exports have remained largely impervious to macroeconomic crises for the last two decades. Despite occasional slow-downs, they have largely kept pace with the growth of world exports. More surprisingly, however, they have impressively expanded since around 2000-01.Turkey's share in world exports rose 60 percent from 0.4 percent in 2000 to 0.7 percent in 2004. Turkey's share in EU external imports increased by the same amount. Only Romania, one of the top export performers among Pan-European economies during that period, matched Turkey's export performance in both EU and world markets. The share of EU-8 in world exports rose 30 percent in 2000-04, that is, less than the respective shares of Turkey and Romania.

While the recent export expansion has been both surprising and impressive, its drivers and consequently ensuing mode of integration into global markets are even more astonishing. Turkey's export basket, although still dominated by unskilled labor intensive products, has been moving quickly towards products characterized by a higher level of processing, medium to high technology content and the use of skilled labor. The major force, albeit not the only one, behind this shift has been the entry of Turkish-based firms into 'producer-driven' networks-automotive and information communication technology networks, which are capital- and skilled-laborintensive industries. In consequence, a number of Turkish firms have become part of a new division of labor based on production fragmentation made possible by the combination of information technology and economic liberalization.

Turkey is the only country among EU candidates whose firms appear to participate in division of labor driven by production fragmentation and their scope of involvement is more extensive than that of firms from some new EU members (EU-8). Together with six EU-8 economies (Hungary, Czech Republic, Slovak Republic, Slovenia, Estonia and Poland), 
Turkey-with the share of 'producer-driven' networks in exports of manufactures, excluding chemicals, exceeding 20 percent in 2003 and double-digit growth rates-has been dubbed in a recent World Bank study (WB 2005) as one of the seven "High Performers" among European and Central Asian countries. Turkey's share of 22.5 percent puts it on a par with Slovenia in 'producer-driven' network trade.

The remainder of the paper is organized as follows. The next Section discusses implications of the "Turkish-EU connection" for contestability of domestic markets and conditions faced by Turkish firms in access to foreign markets. Section 3 examines geographical patterns and dynamics of Turkey's trade in goods and services in the context of EU-8 and other EU candidate economies. Section 4 seeks to examine changes in the degree of processing, technology content and factor intensities of Turkish trade with a special emphasis on trade with the EU and other countries from the Pan-European free trade area for industrial products. Section 5 examines trade in 'buyer-driven' chains, (textiles and clothing, footwear and furniture) and the shift towards 'producer-driven' networks (automotive and Information Communication Technology networks). The last Section concludes.

\section{Contestability of domestic markets and access to external markets}

The pillar defining Turkey's trade policy is preferential relationship, or more precisely the CU (Customs Union) Agreement with the European Union, with enormous implications for both conditions in access of domestic producers to external markets as well as contestability of domestic markets, that is, the extent to which local firms are exposed to competition from imports. The CU Agreement, which went into force on 1 January 1996, has already resulted in Turkey's adoption of the Community's Common Customs Tariff (CCT) for imports of industrial products from the third countries. Turkey has also taken up the EU rules of origin and EU customs procedures (customs valuations, customs declaration, release for free circulation and duty-suspension arrangements). The Agreement has also triggered reforms of technical standards regime and competition policy infrastructure.

The CU Agreement has contributed to a very significant increase in contestability of domestic Turkish markets through infusing predictability, transparency and stability to trade policy as well as by liberalizing market access, i.e., lowering or removal of both tariff and nontariff barrier, for both preferential and MFN suppliers. The extent of liberalization of tariff rates has been very extensive. Consider that MFN applied tariff rates on tradable goods with nonpreferential partners had to be reduced from an average of 22 percent in 1994 to 6.9 percent in 2001, GSP (Generalized System of Preferences) beneficiaries from 22 percent to 2.7 percent, and with the EU's FTA (Free Trade Agreements) partners from 22 percent to 1.34 percent and with the EU from 10.2 percent to 1.34 percent (Togan 1997 and 2000).

Turkey's applied MFN tariff rates for industrial products, the same as those of the EU, represent one of the lowest, if not the lowest, levels of MFN tariff protection among economies at a similar level of economic development. Turkey's both weighted and simple average tariff rates on industrial imports are several times lower than those in other candidate countries.

Tariff rates are not only low but they are also predictable and stable. Since they are tied to EU tariffs as well as comprehensive EU commitments under the WTO agreements, they are resistant to domestic pressures for tariff protection.

As far as non-tariff barriers are concerned, technical barriers to trade have significantly declined with Turkey's gradual transition to the EU technical standards regime. Turkey has made large strides to establish a modern, market based regime of technical regulations and standards. The adoption of international and European standards as well as procedures for admitting goods into Turkey not only increase contestability of domestic markets but also create conditions for 
improved competitiveness of domestic firms in foreign markets.

The CU Agreement and participation in EU trade initiatives has dramatically improved access for Turkish firms not to EU or EFTA markets but also to markets of countries participating in EU Eastern Enlargement project. Turkish producers of industrial goods have had duty-free access to EU markets since 1971, albeit with some exceptions that were removed by 1999. Turkey has already had a FTA with EFTA signed on December 10, 1991, which opened EFTA markets to Turkish industrial exports.

Major new benefits have come from the EU-driven initiative, directly related to EU Eastern Enlargement, to establish Pan-European free trade area for industrial products linked through a system of diagonal cumulation (WTO 1997). The objective of the Pan-European Agreement on Cumulation of the Rules of Origin, which went into effect on January 1, 1997, was to encourage Europe-wide industrial cooperation by diagonal cumulation that would allow treating imports from parties of the agreement as local inputs. The Pan European Cumulation of Origin (PCO) system has encouraged intra industry trade, exports and FDI inflows. ${ }^{1}$ The Agreement has paved the way for establishment in 2002 of a single European trading bloc for industrial products, encompassing the EU-15, EFTA, and ten Central European countries (Bulgaria, Czech Republic, Estonia, Hungary, Latvia, Lithuania, Poland, Romania, Slovakia, and Slovenia). As a party to the Agreement, Turkey signed FTAs with Central European countries in 1997-1999 that eliminated all duties on industrial products by 1 January 2002. This new arrangement allowing unfettered distribution of production capacities in the territory of each signatory of the Pan-European Agreement, without worrying about meeting the rules of origin requirements, has created a very attractive environment for trade.

As a result of these developments, Turkish producers of industrial goods have become exposed to competition from imports and operate in one of the largest, if not the largest, free trade areas in the world. Turkish producers of industrial goods are now protected, in terms of tariffs, from external competition to exactly the same extent as the EU producers are. Moreover, they are not protected by tariffs and have to face competition from duty-free imports of industrial goods from world-class Pan-European firms. In return, industrial producers have duty-free market access, unrestrained by the rules of origins and tariffs, to the European Economic Area (EU-25 and EFTA) and two candidate countries-Bulgaria and Romania. The latter two are geographically close to Turkey. Together with the "Stabilization and Association" partners of the EU from the Balkans (Turkey has either signed or negotiates FTAs), they hold promise to become significant markets for Turkish products in the future. Last but not least, consumers and industrial users of imports have access to cheaper industrial products.

\section{Highlights of Turkey's trade performance: dynamics and geographical reorientation}

The dramatic change over the last decade in trading environment within which Turkish consumers and producers operate raises questions about how they have adapted to it. What have been the major characteristics of Turkey's overall trade performance? How does it compare to other EU-candidates and EU-8 economies? What are its idiosyncratic features, if any? These are the main questions addressed in this section.

\footnotetext{
${ }^{1} \mathrm{EU}$ preferential rules of origin define the requirements for the local content of raw materials, components and value added, including the minimum level of transformation necessary for a product to qualify as originating and thus benefiting from preferential treatment in access to the EU market. Since 1997, a system of European cumulation, based on a network of free trade agreements and protocols, has been established among the EU, the EFTA countries, the Central and Eastern European countries and Turkey. Since 2002, the system was extended to the Southern Mediterranean countries as signatories of Association Agreements with the EU.
} 


\section{A. Trade in goods and services}

Five general features of Turkey's long term trade performance since 1985 stand out. First, except for contraction in 1999, the value of total exports of goods and services has been steadily expanding at the average rate of growth (least square estimate) of 10 percent over 19862004.

Second, imports were highly volatile over 1986-2004 and strongly correlated with GDP growth indicating that exchange rate crises and sharply falling incomes in 1994, 1999 and 2001 have been responsible for contraction in imports (Figure 1). Bursts or implosions in GDP growth rates in nominal terms accompanied similar changes in imports. The coefficient of correlation of annual changes in imports of goods and services and GDP growth rates in 1985-2003 was 88 percent. The same coefficient for exports of goods and services and GDP was 35 percent.

Figure 1: Annual rates of growth in value of exports, imports and GDP in 1990-2004 (in percent)

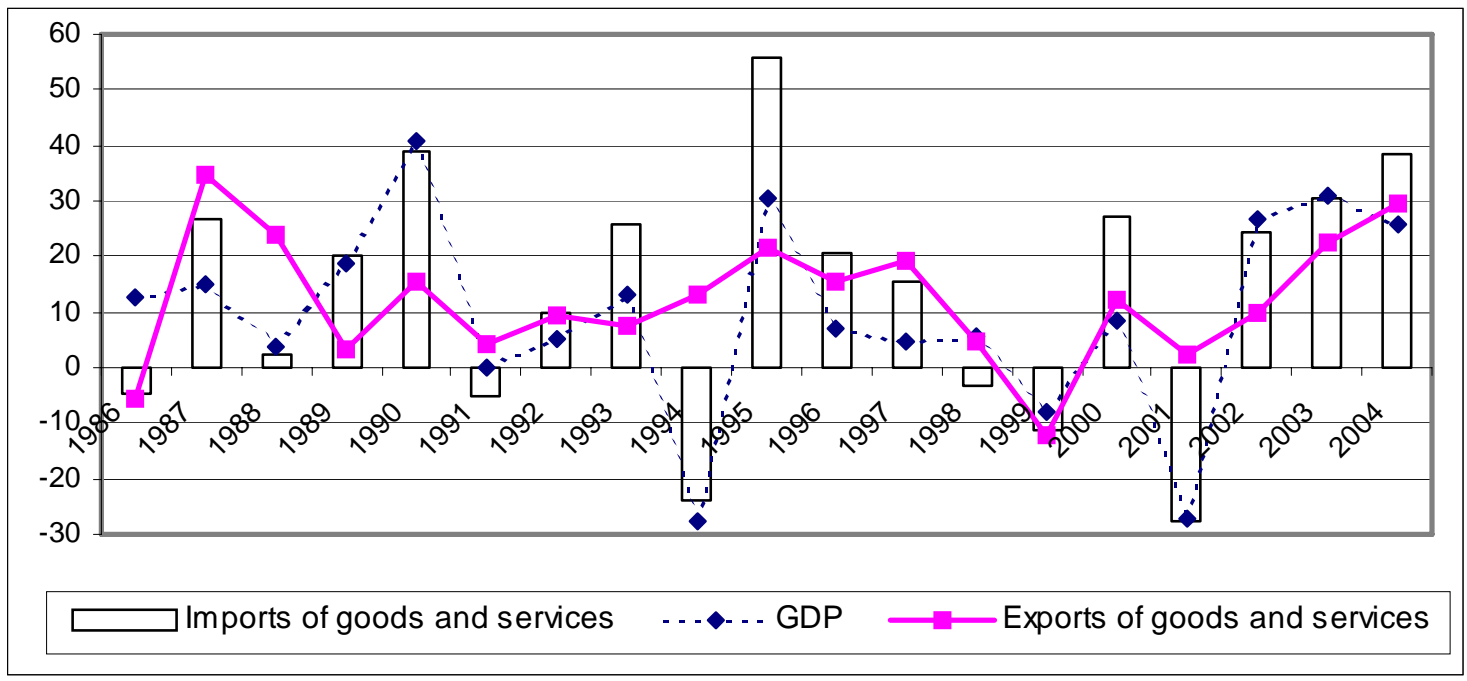

Source: Derived from the World Bank's Development Indicators database.

Third, Turkey's integration and dependence on global markets for goods and service has significantly increased over the last decade. Exports of goods and services as percent of GDP (both in current prices) almost doubled from an average of 16 percent in 1985-90 to 30 percent in 2000-2004. Trade in goods and services in terms of the GDP strongly expanded in the 1990s. The corresponding ratio of 60 percent were more than twice as high in 2000-03 as they were in 199093 (27 percent) indicating rapid increase in reliance of Turkey's economy on external trade in goods and services.

The level of achieved integration into global markets for goods and services is relatively high by regional standards. Although respective values of two indicators expressed in terms of GDP - trade and exports of goods and services-are lower than for EU-8, other EU candidates and South East European (SEE) economies, the differences are not significant. They stem from the size of economy, tourist attractiveness and the level of GDP. Both SEE-4 and EU-8 economies are much smaller, except Poland, and some of them, on top of being much smaller, have also much higher GDP per capita. Both contribute to higher values of openness indicators. Taking into account the size of the economy, Turkey compares favorably with the largest economy among comparators-Poland. Exports of goods and services in percent of GDP are slightly higher in Turkey than in Poland and total trade slightly smaller (Table 1). 
Table 1: Turkey's trade in goods and services as percent of GDP in regional perspective in 1991-98 and 1999-2004 (in percent)

\begin{tabular}{|l|c|c|c|c|}
\hline \multirow{2}{*}{ Country/Group } & \multicolumn{2}{|c|}{ Trade in G\&S as \% of GDP } & \multicolumn{2}{c|}{ Exports of G\&S as \% of GDP } \\
\cline { 2 - 5 } & $1991-98$ & $1999-04$ & $1991-98$ & $1999-04$ \\
\hline Turkey & 42.2 & 57.4 & 19.2 & 27.5 \\
Bulgaria & 95.0 & 114.3 & 47.4 & 53.3 \\
Croatia & 105.0 & 99.5 & 49.4 & 46.1 \\
Romania & 56.3 & 72.3 & 25.1 & 33.1 \\
Memorandum: & & & & 27.0 \\
SEE-4 (simple average) & 75.4 & 76.6 & 24.2 & 56.9 \\
EU-8 (simple average) & 103.6 & 119.0 & 50.7 & 25.2 \\
of which: Poland & 49.2 & 55.4 & 24.2 & \\
\hline
\end{tabular}

SEE-4 includes Albania, Bosnia and Herzegovina, Macedonia and Serbia and Montenegro; EU-8 Czech Republic, Estonia, Hungary, Latvia, Lithuania, Poland, Slovakia and Slovenia.

Source: Computations are based on World Bank WDI data base through SIMA and Turkey's Balance of Payments statistics for 1999-2003.

Fourth, in 1985-2004 Turkey's trade in goods and services has been persistently in the red except for three years-1988, 1994 and 2001 due to deficits in trade in goods. Revenues from exports of goods and services amounted on average to 89 percent of expenditures on imported goods and services in 1990-97 and 92 percent in 1998-2004 (Table 2). The surplus in 2001 affects the average for the last period-excluding 2001 the ratio would be 87 percent. This has been exclusively due to services, which have been a very large net foreign currency earner, with the surplus reaching US\$ 13.5 billion in the peak year of 1998 and 12.8 billion in 2004. Surpluses in trade in services have significantly offset chronic deficits in trade of goods. Over 1998-2004, cumulative surpluses in services amounted to 92 percent of cumulative balances in trade in goods. Surplus in services covered 62 percent of a shortfall in goods trade in 2004.

Table 2: Developments in trade in goods and services in selected years (in billion of US dollars and percent)

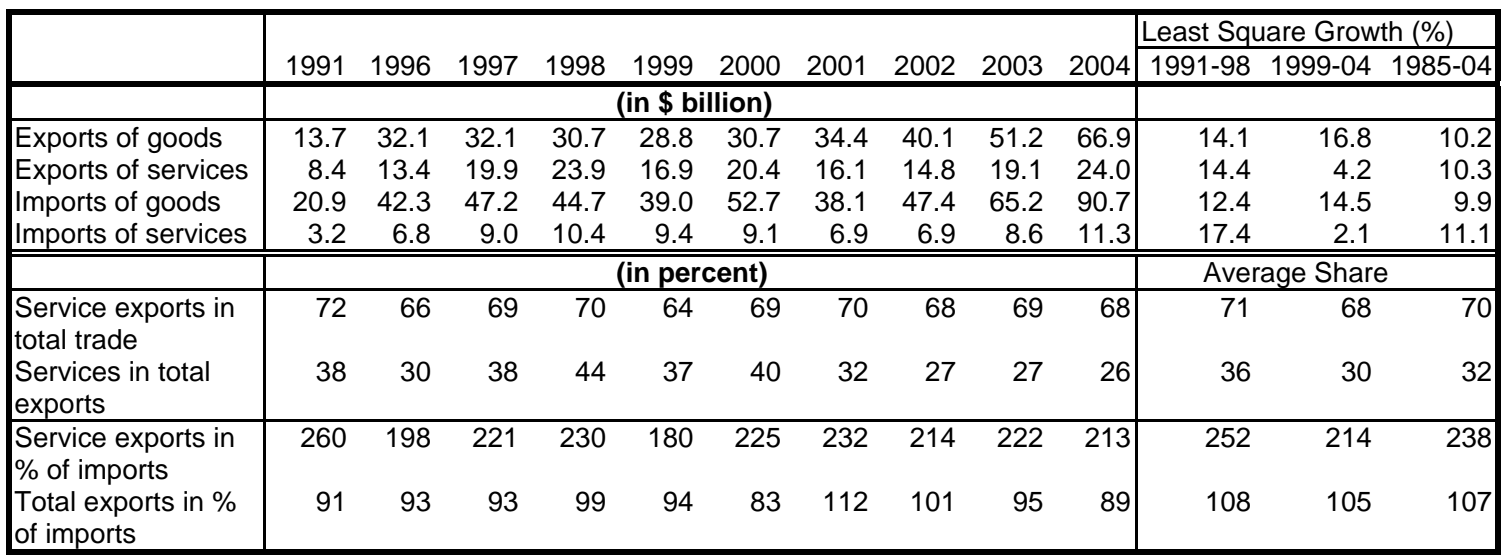

Source: Based on IMF Balance of Payments Statistics through World Bank WDI database.

Fifth, notwithstanding the continuing importance of exports of services as a source of foreign currency earnings, the loss of momentum in their growth in 1998-2004 is rather bewildering. While the value of their exports increased more than eight times between 1985 and 1998 and in terms of GDP doubled, exports of services stagnated in 1998-2004. Their share in total exports fell from 44 percent in 1998 to around 27 percent in 2002-04 (Table 2). This was in large part due to a very strong, double-digit growth of exports of goods.

To sum up, the level of integration of Turkey into global economy has significantly expanded over the last two decades. It is high both in terms of trade in goods and services as well 
as Turkey has been spending significantly more on imported goods and services than it has been receiving in revenues from their exports exclusively due to chronic deficits in trade of goods. In contrast to imports, exports have steadily grown since 1986 except for the contraction in 1999. They have grown faster than the GDP, with their share doubling between 1986 and 2003. Fluctuations of imports seemed to coincide with balance of payments crises and fluctuations in GDP growth rates. Despite recent stagnation in their trade, services continue accounting for a significant portion of total trade. The share of 29 percent in Turkey's exports is roughly the same as in Bulgaria (30 percent), larger than in Romanian exports (15 percent), and much smaller than in export receipts of Croatia (58 percent).

\section{B. Trade in services: puzzling developments in 1998-2004}

Developments in Turkish trade in services in 1998-2004 display bewildering features. Although in line with global trends observed over the last two decades trade in services was growing on average at a double-digit growth rate in 1985-98, ${ }^{2}$ the expansion came to a screeching halt in 1999-2004. During this period, trade in commercial services (excluding government services) was unusually volatile, characterized by huge swings, with exports and imports moving in tandem. Furthermore, there was a significant change in the composition of this trade and, except for revenue from tourism, export performance was poor.

Total trade turnover in services was falling each year except in 2000 in 1999-2002. It took off in 2002-03 growing on average 24.2 percent. In spite of two years of double-digit growth rates in 2003 and 2004, the value of services trade turnover was in 2004 only 2 percent higher than in 1998. Both exports and imports were responsible for this performance. Imports fell each year in 1999-2002 and displayed strong growth in 2003-04. Exports were volatile, although beginning in 2000; they displayed similar dynamics as their imports (Table 3 and Figure 2).

But a recent rebound in both exports and imports of commercial services does not put the issue of the 1998-2002 troughs to the dustbin of history. Leaving aside the fact that the data are in current dollar values, trade turnover in services others than travel and transport dramatically declined over 1998-2004. In 2004, its value was at 9 percent of its peak level in 1998 and 23 percent of the level in 2000, despite doubling in 2004 over 2003. In terms of GDP, trade in services amounted on average to 12 percent in 2002-04 down from the average of 15 percent in 1998-2001.

While both receipts from sale of services and expenditures displayed striking volatility over 1998-2004, exports in terms of imports-except in 1999-have remained remarkably stable over this period, despite the falling surpluses in services balance excluding transport and travel. Exports of these other services in terms of their imports fell from to 234 percent in 1998 to 135 percent in 2004 (see Table 3).

\footnotetext{
${ }^{2}$ The share of commercial services in world exports of goods and services increased from 15 percent to 20 percent over the last two decades. See Maurer and Chauvet 2002.
} 
Table 3: Exports and imports of commercial services with and without transport and travel services in 1998-2004 (in million of US dollars)

\begin{tabular}{|c|c|c|c|c|c|c|c|}
\hline & 1998 & 1999 & 2000 & 2001 & 2002 & 2003 & 2004 \\
\hline Exports of commercial services & 23,526 & 16,590 & 20,112 & 15,884 & 14,722 & 18,928 & 23,788 \\
\hline Imports of commercial services & 9,761 & 8,813 & 8,467 & 6,435 & 6,271 & 7,708 & 10,280 \\
\hline Exports in \% of imports & 241 & 188 & 238 & 247 & 235 & 246 & 231 \\
\hline Exports excluding travel and transportation & 13,229 & 8,487 & 9,521 & 4,940 & 3,448 & 3,541 & 4,633 \\
\hline Imports excluding travel and transportation & 5,642 & 5,241 & 4,291 & 2,676 & 2,457 & 2,888 & 3,425 \\
\hline Exports in \% of imports & 234 & 162 & 222 & 185 & 140 & 123 & 135 \\
\hline
\end{tabular}

Source: Balance of payments statistics.

Figure 2: Change in exports and imports of commercial services $(1998=100)$

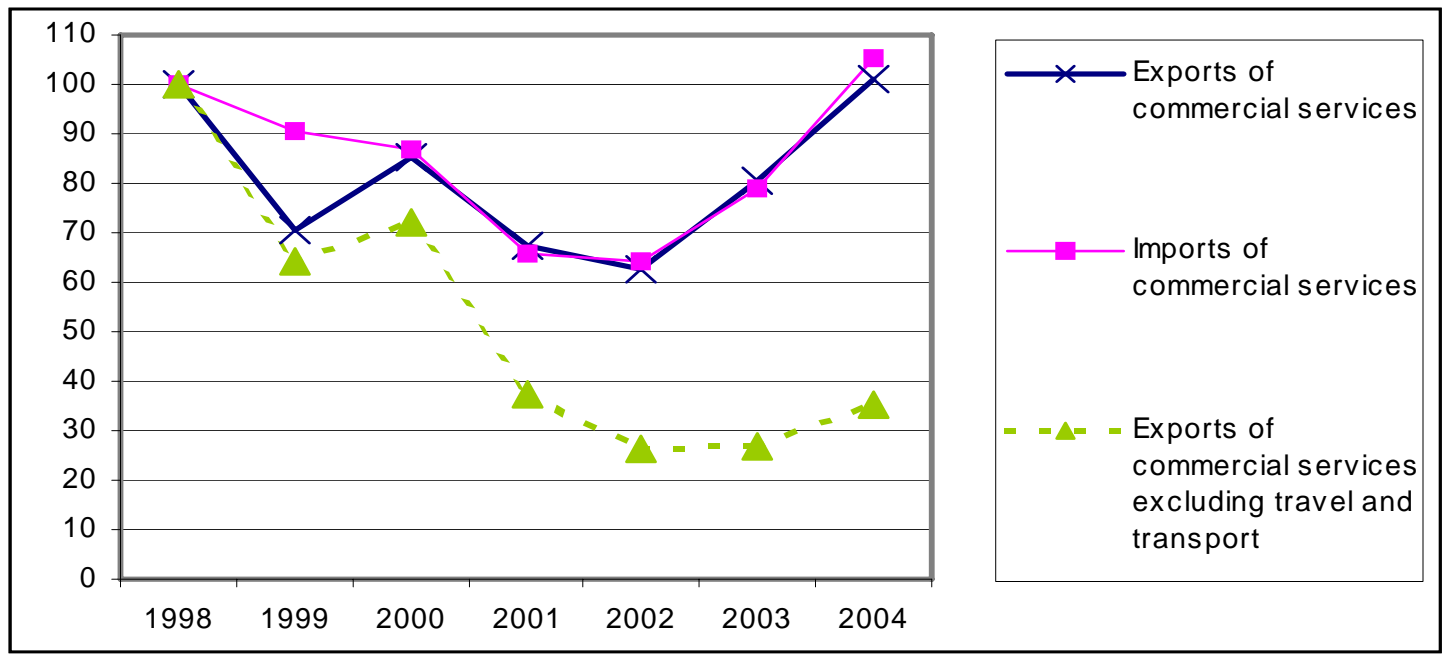

Source: Balance of payments statistics.

Because of the strong performance of tourism, the decline in trade turnover of other services and the collapse in exports of other commercial services (excluding travel and transport) had no impact on the ratio of exports to imports of commercial services. Annual changes in the value of exports varied in the range between -29 percent and +29 percent and in the value of imports between -24 percent and +33 percent. Moreover, they coincided in time-the value of the correlation coefficient for annual changes in 1999-2004 is high at 81 percent. In consequence, exports in terms of imports remained stable - the average ratio for the 1998-2004 period was 2.32, with a low value of the coefficient of variation of 0.09 and standard deviation of 0.20 .

While undoubtedly earthquakes, war in Iraq and perceptions of instabilities in the Middle East might have suppressed tourism in the region, tourism (travel services) recorded hefty growth in current US dollars of 15.5 percent per year in 1998-2004. It was the only item that did not experience contraction in exports in terms of value over this period. But its performance was not sufficiently robust to offset the decline in other exports, as total receipts had a negative growth rate in 1998-2004. Among other categories of services, the strongest performer was transport, with the average annual, negative growth rate of (-) 1.5 percent in 1998-2004.

Stagnation in exports of services over 1999-2004 was the result of the collapse of receipts from sales of all services sectors identified in balance of payments statistics except for tourism and transport (Table 4). The aggregate receipts from other sectors stood in 2004 at 55 percent of their level in 1999 and 35 percent of their level in 1998. The inclusion of transport does not significantly alter the overall picture-revenues in 2004 were 37 percent below their 1999 level and 52 percent below their level in 2000. 
Table 4: Composition of exports of services and their exports in terms of imports in 1998-2004

\begin{tabular}{|c|c|c|c|c|c|c|c|}
\hline & & & & & & \multicolumn{2}{|c|}{ Memorandum: change in value } \\
\hline & 2000 & 2001 & 2002 & 2003 & 2004 & Index, 2002 & Index, 2004 \\
\hline & \multicolumn{5}{|c|}{ Receipts from services exports } & $2000=100$ & $1999=100$ \\
\hline Transport & $15 \%$ & $18 \%$ & $19 \%$ & $12 \%$ & $14 \%$ & 95 & 113 \\
\hline Travel & $38 \%$ & $51 \%$ & $58 \%$ & $70 \%$ & $67 \%$ & 111 & 305 \\
\hline Construction & $5 \%$ & $4 \%$ & $6 \%$ & $4 \%$ & $3 \%$ & 86 & 66 \\
\hline Other commercial services & $28 \%$ & $18 \%$ & $7 \%$ & $7 \%$ & $7 \%$ & 18 & 36 \\
\hline Insurance and financial services & $2 \%$ & $2 \%$ & $2 \%$ & $2 \%$ & $1 \%$ & 60 & 90 \\
\hline \multirow[t]{2}{*}{ Other services } & $13 \%$ & $7 \%$ & $9 \%$ & $6 \%$ & $9 \%$ & 53 & 77 \\
\hline & \multicolumn{5}{|c|}{ Exports in terms of imports } & & \\
\hline Transport services & 120 & 141 & 145 & 81 & 75 & 79 & 206 \\
\hline Travel services & 446 & 465 & 451 & 625 & 629 & 110 & 172 \\
\hline Other commercial services & 376 & 246 & 94 & 98 & 109 & 73 & 137 \\
\hline Insurance and financial services & 55 & 46 & 36 & 78 & 76 & 93 & 60 \\
\hline Other services & 123 & 139 & 183 & 107 & 128 & 35 & 45 \\
\hline
\end{tabular}

Source: IMF Balance of Payments statistics.

And a cursory examination of trade developments in various categories of services does not alter the picture. In fact, it raises a lot of new questions but offers few, if any, answers, with developments in some instances defying common wisdom. For instance, considering revealed comparative advantage of Turkish construction companies, supported among others by press information about construction bids won abroad (e.g., airports in Cairo and Moscow), a 34 percent lower level of their foreign activities in terms of value in 2004 as compared to 1999 is difficult to explain. Similarly, the decline in both exports and imports of insurance and financial services would be tough to explain in view of the restructuring of the financial sector and burgeoning trade in goods in 2001-2004. In a similar vein, consider the developments in transport services juxtaposed against trade in goods and the expansion in 'producer-driven' network trade (See Section 5). The value of total trade turnover in goods in 2004 more was more than twice (2.16) as high as its value in 2001, while trade in transport services rose merely 56 percent or slightly more than half of the increase in goods trade. Simultaneously, 'producer-driven' network trade, critically dependent on smooth functioning of logistic services blocs, has been the driver of this expansion with its share in total trade turnover increasing from 15 percent in 2000 to 17 percent in 2003. It is hard to imagine that this two-way trade has not involved provision of transport and other services paid or provided by non-resident providers.

While the relationship between growth in goods trade and transport services purchased abroad or sold to foreign contractors is rarely linear, the gap between respective increases is seldom that high. It is even more unusual when they move in opposite direction as trade in goods and trade in transport services did in 1999-2003, with the ratio of the latter to the former falling from 7.5 percent in 1999 to 6.8 percent in 2001 and 4.3 percent in 2003. The ratio slightly rebounded to 4.9 percent in 2004.

Furthermore, the developments in Turkey's services trade in categories other than travel and, to a lesser extent, transport, in 1999-2004 defy trends observed worldwide. We may safely assume that other service categories lumped together cover, among others, trade in computer, business and other services (see Table 3 above), which is used as a proxy for outsourcing (the contracting of business functions to an outside suppliers). A dramatic decline in other than travel and transport services trade from US\$ 5.2 billion in 2000 to US\$ 1.2 billion in 2004 indicates that Turkish firms failed to attract offshore services. Countries that have attracted business services are not only the English-speaking ones, although India and Ireland have been very successful. In 2003 Estonia, China and Morocco recorded the largest increase exports of computer and business services - the value of these exports over a previous year increased 70 percent, 68 percent and 61 percent respectively.

Thus, the critical question is what happened to trade in services in other categories than 
travel and transport; although the latter's poor performance remains unanswered. It is not clear what explains volatility and collapse in their trade. It remains unclear whether unusual patterns in Turkish trade in services are simply a statistical mirage or they reflect deeper structural barriers to this trade. Given its performance in trade in goods, one is tempted to blame the quality of statistics rather than idiosyncrasies of Turkey's mode of integrating into global economy. Whatever the answer might be, it needs to be found simply because services statistics provide important inputs to economic policy making.

C. Trade in goods and services in comparative perspective: expanding aggregate trade openness

Looking solely at trade turnover per capita does not provide a good base for an assessment of a country's involvement in world trade (Figure 3). Turkey's trade turnover per capita in 2004 puts it close to the bottom of EU-8, SEE-3 and EU candidate economies. It is higher than only trade turnover per capita of Macedonia, Serbia and Montenegro and Albania. On the other hand, however, Turkey's turnover is pretty close to Romania's trade turnover per capita. But this is highly misleading, as Turkey's population is almost double that of the largest country among the EU-8, Poland; more than triple of that of Romania (the second most populous country); and 52 times larger than the least populous, Estonia. Larger population implies a larger domestic economy less dependent on foreign trade.

Figure 3: Trade in goods per capita in Turkey and other 'EU-related' European countries in 2004 (in US dollars)

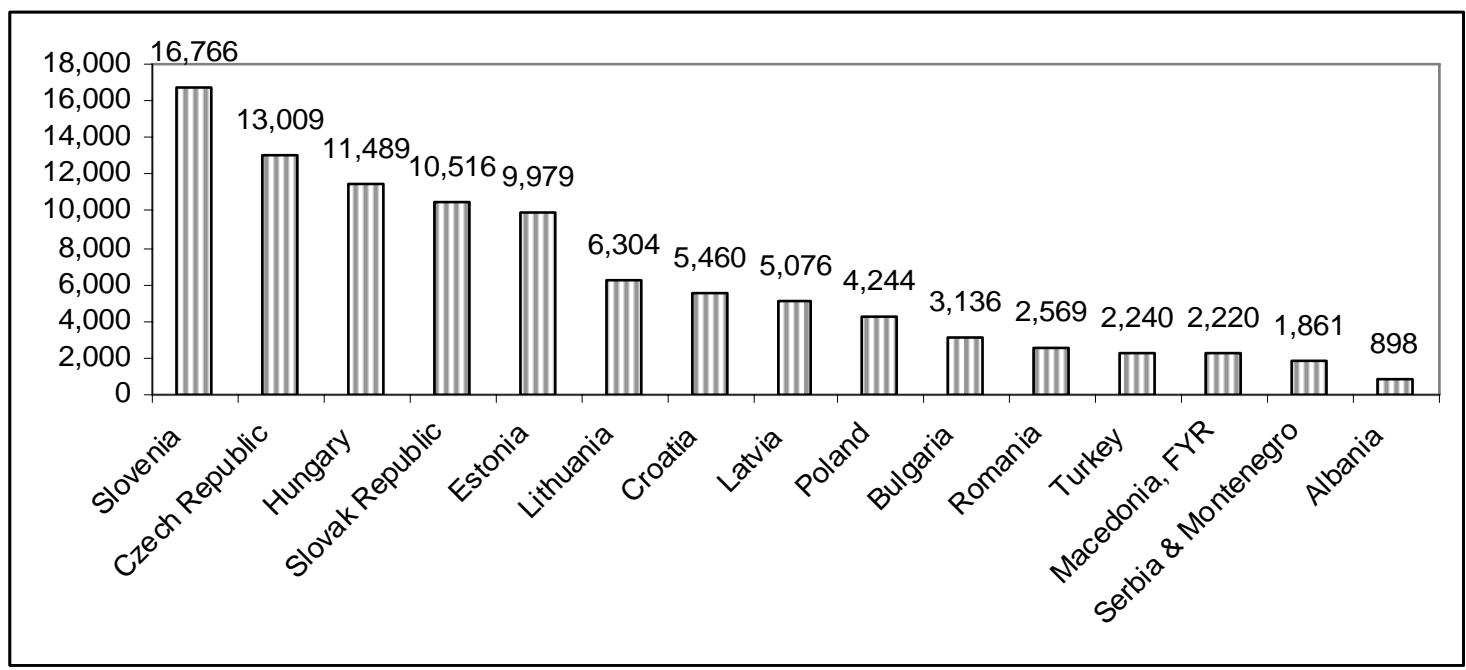

Source: Trade as reported to the UN COMTRADE database and population data from WDI.

In fact, Turkey ranks very high in terms of trade openness and integration into global markets if variables determining a country's dependence on foreign trade are taken into account. Its actual trade relative to GDP in 2003 exceeded the level generated by an empirical model developed for 149 countries. The model regresses openness, defined as the share of goods in GDP, on the country's population, distance to major markets and GDP per capita (World Bank 2005). Its results are theoretical or potential shares of goods exports and imports in the GDP. If the potential (predicted) share is below its actual share, then a country 'under-trades.' If the reverse is the case, then a country's involvement in global trade is larger than its size, level of economic development, as proxied by the GDP per capita, and distance to world's most important markets would indicate.

Turkey like most of new Central European members of the EU (EU-8) appears to be 
measurably over-trading by around one-third. Turkey's 2003 realization ratio of 1.31 indicates that the actual ratio of trade to GDP (25 percent) was 31 percent over its ratio predicted by the model. It compares very favorably with the level of openness of new Central European members of the EU (EU-8), which had the average realization ratio of 1.35. Turkey's realization ratio was roughly similar as Slovenia's (1.33) but higher than that for Bulgaria (0.94) and Poland (0.92), both traded below their respective potential, Romania (1.02), Latvia (1.04), Lithuania (1.09) as well as above the average for other Balkan countries (0.65). Each country of the latter as a group traded well below its current potential as reflected by the estimated model.

Turkey's trade integration into global markets for goods has significantly expanded over the last two decades. This was mainly the result of expanding exports in the second half of the 1980s and in the 2000s. Turkey's share in world imports remained relatively unchanged in 19902003 at around 0.8 percent, although it displayed an upward trend in 2000-2004. Its share in world exports, however, rose rather dramatically by 50 percent in 2000-2003. This was in marked contrast to the developments in the 1990s when Turkey exports growth simply kept with the pace of the growth of world exports. Turkey's share of 0.4 percent was relatively stable throughout the 1990s (Table 5).

Table 5: Turkey in world trade in regional perspective in 1993, 1996 and 2004

\begin{tabular}{|c|c|c|c|c|c|c|c|c|c|c|c|c|}
\hline & & & \multirow{2}{*}{\multicolumn{2}{|c|}{1996}} & \multirow{2}{*}{\multicolumn{2}{|c|}{2000}} & \multirow{2}{*}{\multicolumn{2}{|c|}{2004}} & \multicolumn{4}{|c|}{ Change in percent (\%) } \\
\hline & \multicolumn{2}{|c|}{1993} & & & & & & & \multicolumn{2}{|c|}{ 1993-2004 } & \multicolumn{2}{|c|}{$2000-2004$} \\
\hline & \multicolumn{2}{|c|}{ Exports Imports } & \multicolumn{2}{|c|}{ Exports Imports } & \multicolumn{2}{|c|}{ Exports Imports } & \multicolumn{2}{|c|}{ Exports Imports } & Exports & Imports & Exports & Imports \\
\hline & \multicolumn{6}{|c|}{ Value in billion of US dollar } & & & & & & \\
\hline Turkey & 15.3 & 29.4 & 23.1 & 42.5 & 27.8 & 54.5 & 62.9 & 97.3 & 310 & 232 & 127 & 79 \\
\hline EU-8 & 49.2 & 62.2 & 83.6 & 115.4 & 118.8 & 154.1 & 254.5 & 297.9 & 417 & 379 & 114 & 93 \\
\hline Bulgaria & 2.3 & 4.5 & 4.8 & 4.9 & 4.8 & 6.4 & 9.4 & 14.2 & 304 & 216 & 97 & 123 \\
\hline \multirow[t]{2}{*}{ Romania } & 4.9 & 6.5 & 7.6 & 10.0 & 10.4 & 13.1 & 23.5 & 32.6 & 380 & 399 & 126 & 150 \\
\hline & \multicolumn{6}{|c|}{ Share in world (in \%) } & & & & & & \\
\hline Turkey & 0.41 & 0.77 & 0.44 & 0.79 & 0.43 & 0.83 & 0.69 & 1.03 & 68 & 33 & 59 & 24 \\
\hline EU-8 & 1.32 & 1.64 & 1.58 & 2.14 & 1.86 & 2.34 & 2.80 & 3.15 & 111 & 92 & 50 & 35 \\
\hline Bulgaria & 0.06 & 0.12 & 0.09 & 0.09 & 0.07 & 0.10 & 0.10 & 0.15 & 65 & 27 & 38 & 55 \\
\hline Romania & 0.13 & 0.17 & 0.14 & 0.18 & 0.16 & 0.20 & 0.26 & 0.34 & 96 & 100 & 59 & 74 \\
\hline
\end{tabular}

Notes: EU-8 countries are the Czech Republic, Estonia, Hungary, Latvia, Lithuania, Poland, Slovak Republic and Slovenia.

Source: IMF DOT Statistics.

Turkey's export performance has been in line with that of EU-8 and Romania and well above Bulgaria's performance. The latter's share in world exports in 2003 was slightly below in 1993, whereas that of Turkey was 52 percent higher. The difference between Turkey and EU-8 and Romania is relatively small considering that dynamics of geographic reorientation of trade away from the former Soviet Union drove their trade in 1992-96 following the collapse of central planning. While between 1990 and 1993, exports from Turkey were growing at roughly the same pace as those from the EU-8, the situation subsequently changed. The ratio of EU-8 share in world exports to that of Turkey increased from 3.2 in 1990 and 1993 to 4.3 in 2000 and then fell to 4 in 2004 indicating Turkey's stronger export growth performance (based on IMF DOT statistics).

Indeed, Turkey's share in world exports rose 59 percent from 0.4 percent in 2000 to 0.7 percent in 2004 while that of the EU-8 as a group rose 50 percent. Only Romania the top export performer among Central European countries during that period-matched Turkey's record.

On the other hand, Turkey had the weakest performance among these countries in terms of imports. Its share in world imports, like that in exports, did not budge in the 1990s. It increased 
merely 24 percent in 2004 over 2000, which was by far the smallest increase among comparators. Since export growth was so much stronger, with the export coverage of imports rising from 58 percent in 2000 to 74 percent in 2004, it would appear that import content of exports has declined as domestically produced inputs replaced imports.

In spite of these developments, Turkey's aggregate trade openness (goods exports plus imports to GDP) increased from an average of 32 percent in 1990-99 to 48 percent in 2000-04. It was also well above the level indicated by Turkey's size, GDP per capita and distance from major world's markets. From this perspective, Turkey has been as successful as Slovenia.

Exports of goods were a bright spot in Turkey's overall performance in 2000-04. The export performance gap between EU-8 and Turkey, which significantly increased between 1993 and 2000, similarly considerably fell in 2000-03, although it remained higher than in 1990 and 1993. Turkey's export performance has been strongly reminiscent of that of Romania, a late reformer among transition economies, whose exports dramatically picked up in the late 1990s and early 2000s. Both countries registered a 50 percent increase in respective shares in world exports.

While, as discussed earlier, statistics on Turkey's performance in trade in services raise doubts as to their quality, Turkey's overall position in terms of services trade per capita vis-à-vis other EU associates and new members is similar to that in trade in goods. It is above the levels in two former Yugoslav republics-Macedonia and Serbia and Montenegro-and Romania, which swapped respective positions in the ranking with Albania (Figure 4).

Figure 4: Trade in services per capita in Turkey and other 'EU related' countries in 2004 (in US dollars)

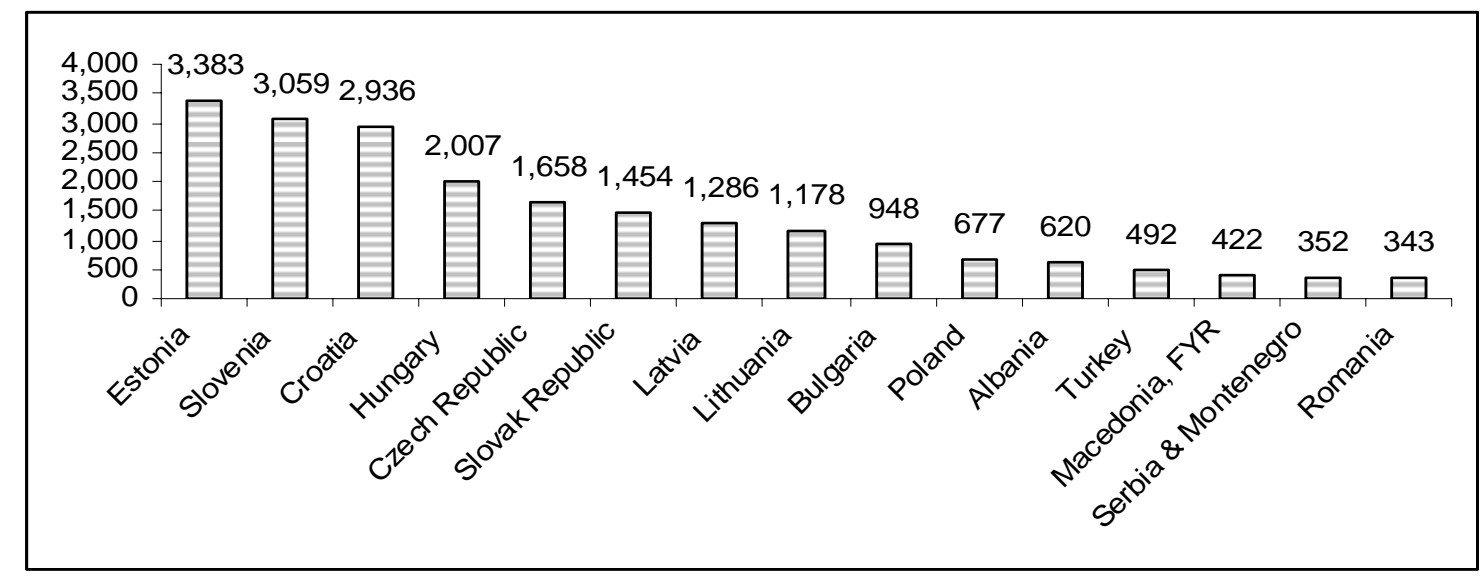

Source: IMF Balance of Payments database.

Trade in services plays, however, much more important role in Turkey's trade than per capita statistics would indicate. The share of services in total trade was 18 percent in 2004, which is well above this share in trade of most other "EU-related' European economies. Albania (41\%), Croatia (35\%), Estonia (25\%) and Latvia (20\%) had a higher share of services in total trade.

\section{Reorientation of foreign trade away from Middle East towards Pan-European markets}

A very significant reorientation of Turkey's foreign trade towards the EU did not occur after entry into force of the EU-Turkey Customs Union Agreement on 1 January 1996 but much earlier. In fact, 1996 marked historically the highest share of the EU-15 in Turkey's total trade turnover. The striking feature of Turkey's dynamics in geographical pattern of foreign trade has been the stability in the share of the EU-25 in total trade turnover since 1996. Interestingly, the 
disruption in the earlier observed trend of the expanding trade with the EU-15, with its share increasing from 40 percent in 1985 to 50 percent in 1995, coincided with the entry into force of the Customs Union Agreement. Subsequently, the share remained at around 50 percent in 19962000, fell to 47 percent in 2001 and stabilized at 48 percent in 2002-03 (Table 6).

Table 6: Direction and dynamics of Turkey's trade in 1985, 1995 and 2001-2004 (in million of US dollars and percent)

\begin{tabular}{|c|c|c|c|c|c|c|c|c|c|c|c|c|}
\hline \multirow[b]{2}{*}{ Partner } & \multicolumn{5}{|c|}{ Exports (\$ million) } & \multirow{2}{*}{\begin{tabular}{|l|l|}
$\begin{array}{l}2000 \\
\text { Index }\end{array}$ \\
$1995=100$ \\
\end{tabular}} & \multirow{2}{*}{\begin{tabular}{|l|}
$\begin{array}{l}2004 \\
\text { index }\end{array}$ \\
$2000=100$ \\
\end{tabular}} & \multicolumn{5}{|c|}{ Export Share (\%) } \\
\hline & 1985 & 1995 & 2002 & 2003 & 2004 & & & 1985 & 1995 & 2002 & 2003 & 2004 \\
\hline Pan-Euro: of which & 3,693 & 12,695 & 20,886 & 28,255 & 37,694 & 127 & 234 & 46.4 & 58.8 & 58.4 & 59.8 & 59.7 \\
\hline $\mathrm{EU}(15)$ & 3,398 & 11,077 & 18,331 & 24,488 & 32,575 & 130 & 226 & 42.7 & 51.3 & 51.3 & 51.8 & 51.6 \\
\hline EU-10 & 107 & 840 & 1,210 & 1,734 & 2,332 & 97 & 285 & 1.4 & 3.9 & 3.4 & 3.7 & 3.7 \\
\hline $\mathrm{EU}(25)$ & 3,506 & 11,917 & 19,541 & 26,222 & 34,907 & 128 & 229 & 44.1 & 55.2 & 54.6 & 55.5 & 55.3 \\
\hline EFTA(3) & 133 & 293 & 406 & 538 & 658 & 110 & 204 & 1.7 & 1.4 & 1.1 & 1.1 & 1.0 \\
\hline Bulgaria & 8 & 183 & 378 & 622 & 894 & 138 & 355 & 0.1 & 0.8 & 1.1 & 1.3 & 1.4 \\
\hline Romania & 47 & 302 & 560 & 873 & 1,235 & 108 & 380 & 0.6 & 1.4 & 1.6 & 1.8 & 2.0 \\
\hline ROW: of which & 4,265 & 8,904 & 14,876 & 18,998 & 25,426 & 127 & 224 & 53.6 & 41.2 & 41.6 & 40.2 & 40.3 \\
\hline SEE(5) & 33 & 166 & 386 & 570 & 740 & 191 & 233 & 0.4 & 0.8 & 1.1 & 1.2 & 1.2 \\
\hline $\operatorname{NAFTA(3)}$ & 527 & 1,616 & 3,654 & 4,016 & 5,343 & 203 & 163 & 6.6 & 7.5 & 10.2 & 8.5 & 8.5 \\
\hline Russia & 0 & 1,232 & 1,168 & 1,368 & 1,859 & 52 & 291 & .. & 5.7 & 3.3 & 2.9 & 2.9 \\
\hline East Asia & 44 & 340 & 541 & 955 & 758 & 59 & 380 & 0.5 & 1.6 & 1.5 & 2.0 & 1.2 \\
\hline MENA & 3,315 & 3,019 & 4,298 & 6,567 & 9,512 & 107 & 295 & 41.7 & 14.0 & 12.0 & 13.9 & 15.1 \\
\hline \multirow[t]{2}{*}{ World } & 7,958 & 21,599 & 35,762 & 47,253 & 63,121 & 127 & 230 & 100 & 100 & 100 & 100 & 100 \\
\hline & \multicolumn{5}{|c|}{ Imports (\$ million) } & & & \multicolumn{5}{|c|}{ Import Share (\%) } \\
\hline Pan-Euro: of which & 4,706 & 18,931 & 28,148 & 38,570 & 52,045 & 156 & 176 & 41.5 & 53.0 & 54.9 & 55.6 & 53.4 \\
\hline $\mathrm{EU}(15)$ & 4,228 & 16,862 & 23,289 & 31,696 & 42,359 & 157 & 160 & 37.3 & 47.2 & 45.4 & 45.7 & 43.4 \\
\hline EU-10 & 111 & 407 & 1,214 & 1,833 & 3,116 & 191 & 401 & 1.0 & 1.1 & 2.4 & 2.6 & 3.2 \\
\hline $\mathrm{EU}(25)$ & 4,339 & 17,269 & 24,502 & 33,529 & 45,475 & 158 & 167 & 38.3 & 48.4 & 47.8 & 48.4 & 46.6 \\
\hline EFTA(3) & 205 & 892 & 2,483 & 3,396 & 3,911 & 129 & 340 & 1.8 & 2.5 & 4.8 & 4.9 & 4.0 \\
\hline Bulgaria & 99 & 402 & 507 & 689 & 959 & 115 & 207 & 0.9 & 1.1 & 1.0 & 1.0 & 1.0 \\
\hline Romania & 64 & 368 & 657 & 956 & 1,700 & 183 & 253 & 0.6 & 1.0 & 1.3 & 1.4 & 1.7 \\
\hline ROW: of which & 6,634 & 16,777 & 23,122 & 30,770 & 45,495 & 147 & 185 & 58.5 & 47.0 & 45.1 & 44.4 & 46.6 \\
\hline SEE(5) & 114 & 61 & 46 & 87 & 202 & 153 & 216 & 1.0 & 0.2 & 0.1 & 0.1 & 0.2 \\
\hline $\operatorname{NAFTA(3)}$ & 1,322 & 4,101 & 3,434 & 3,841 & 5,234 & 102 & 125 & 11.7 & 11.5 & 6.7 & 5.5 & 5.4 \\
\hline Russia & 0 & 2,082 & 3,863 & 5,451 & 9,033 & 186 & 233 & ". & 5.8 & 7.5 & 7.9 & 9.3 \\
\hline East Asia & 160 & 1,023 & 2,218 & 3,865 & 6,451 & 205 & 307 & 1.4 & 2.9 & 4.3 & 5.6 & 6.6 \\
\hline MENA & 3,669 & 3,830 & 5,065 & 6,577 & 8,373 & 140 & 156 & 32.4 & 10.7 & 9.9 & 9.5 & 8.6 \\
\hline World & 11,341 & 35,707 & 51,270 & 69,340 & 97,540 & 152 & 180 & 100 & 100 & 100 & 100 & 100 \\
\hline
\end{tabular}

Notes: EU-10 includes new members of the EU as of May 1, 2004 (Cyprus, Czech Republic, Estonia, Hungary, Malta, Latvia, Lithuania, Poland, Slovakia and Slovenia); SEE-5 includes Albania, Bosnia and Herzegovina, Croatia, Macedonia and Serbia and Montenegro: NAFTA-3 includes Canada, Mexico and the U.S.;MENA refers to Middle-East and North Africa and EFTA-3 include Iceland, Norway and Switzerland. Source: Derived from UN COMTRADE database as reported by Turkey.

A dramatic fall in the importance of Middle East and North Africa in Turkey's trade turnover accompanied reorientation of trade towards the EU-15 in 1985-1990. While Middle East and North African countries accounted for 36 percent of total trade turnover in 1985, this share fell to 17 percent in 1990. Subsequently, trade turnover with this region has kept pace with Turkey's total trade, with its share remaining at 11-12 percent. ${ }^{3}$ Had the share of Middle East and North Africa remained at its 1985 level, the share of the EU-15 would have remained unchanged

\footnotetext{
${ }^{3}$ MENA countries took 74 percent of Turkish exports to ROW in 1985 and only 31 percent in 1995-2003. Imports from MENA accounted for 52 percent in 1985. By 1995 they fell to 21 percent and 18 percent of ROW imports in 2003.
} 
at around 40 percent in 1985-2004 and trade with MENA would have amounted to US\$ 42 billion rather than US\$ 18 billion in 2004, despite its significant increase in 2004. The aggregate value of exports to this region increased 53 percent in 2004 as compared with the increase of total exports amounting to 34 percent.

The inclusion of other Pan-European partners changes the overall picture, as their share in Turkey's trade expanded until 2002 growing from 4 percent in 1985 to 9 percent of total trade in 2002 and 2003. This drove up the share of Pan-European countries in Turkish trade from 55 percent in 1995 to 57 percent in 2003. Their aggregate share in exports increased from 59 percent in 1995 to 60 percent in 2003 and in imports from 53 percent to 56 percent in respective years (Table 6 above).

These comments notwithstanding, Turkey's integration into Pan-European markets appears to be higher and deeper than the respective shares alone would suggest. High levels of intra-industry and intra-product trade (see Sections 3 and 4) tie together production facilities across Pan-European borders. Furthermore, despite sluggish import demand in three Turkey's major trading partners in the EU-Germany, Italy and France-taking together 30 percent of its exports, Turkish exports experienced impressive growth rates and Pan-European markets have driven this growth. The expansion in exports to Bulgaria and Romania is particularly noteworthy.

\section{E. Dynamics and factors accountable for growth of EU-destined exports in regional perspective}

Turkey's export performance in EU-markets has been impressive even when cast against other EU Eastern Enlargement countries-EU-8 and EU candidate countries. Turkey continued its preferential commercial relations with the EU in the 1990s that began with the 1963 Ankara Agreement, whereas EU-8 together with Bulgaria and Romania had an extra, one-time potential for trade expansion following the collapse of central planning in 1989-90. Since central planning collapsed about a decade after the process of trade liberalization began in Turkey and Central European countries obtained duty-free access to EU industrial markets around two decades later than Turkey, one-time redirection combined with catch-up dynamics had driven their EU-oriented exports in the 1990s. These factors were not present in Turkish performance, as trade with the EU was not suppressed by market access or political considerations related to the now-defunct Council for Mutual Economic Assistance regional arrangements. Hence, no similarly extraordinary factors shaped Turkish trade with the EU in the 1990s.

The developments in the 1990s fully corroborated these expectations, albeit with two caveats. First, transition economies that swiftly implemented first-generation reforms (price, foreign trade and exchange rate liberalization) indeed experienced massive growth of EUoriented exports already in the early 1990s. Those that delayed them or aborted them either entered the path of strong growth in the late 1990s (Romania) or only recently (Bulgaria), albeit the latter at less impressive growth rates. Second, the gap between Turkey's performance and that of EU-8 economies was smaller than one might anticipate and was closed over the last five years. Furthermore, Turkey consistently outperformed two other EU candidate countries-Bulgaria and Croatia-in 1993-2004.

The data, both in current values and in terms of shares in EU external imports, provide empirical support to these observations. Since changes in the exchange rate of the US dollar visà-vis Euro may distort dynamics of exports even examined in a comparative perspective, Table 7 and Figure 5 present the evolution of shares of Turkey in EU external imports against those of its regional partners-EU-8, Bulgaria, Croatia and Romania. First, leaving aside Croatia, other groups or countries-including both Bulgaria and Romania-registered much larger increase in their respective shares in EU external imports than Turkey in 1993-96. Turkey's share was 14 percent larger at the end of this period, Bulgaria's 29 percent and EU-8 63 percent. But two years later in 1998, Turkey's share was 13 percent over its 1996-level, Bulgaria's also 13 percent, 
Romania's 19 percent and EU-8 16 percent. Overall, between 1993-99 Turkish exports outpaced growth in EU-25 external demand to the tune of 5 percent, which was above the performance of Bulgaria (4 percent) and Croatia (-2 percent), but below that of Romania (10 percent) or EU-8 (12 percent).

Table 7: EU-25 external imports from EU candidate states in 1996-2004 and their shares in EU25 external imports (in percent and billion of US dollars)

\begin{tabular}{|c|c|c|c|c|c|c|c|c|c|c|c|c|c|c|}
\hline \multirow[b]{2}{*}{ Partner } & \multicolumn{10}{|c|}{ EU25 Imports ( $\$$ billion) } & \multicolumn{2}{|c|}{$\begin{array}{|ll|}1996 & 2004 \\
\text { Index } & \text { index } \\
\end{array}$} & \multicolumn{2}{|c|}{$\begin{array}{l}\text { Least Sq. } \\
\text { Growth (\%) }\end{array}$} \\
\hline & 1993 & 1996 & 1997 & 1998 & 1999 & 2000 & 2001 & 2002 & 2003 & 2004 & $\begin{array}{r}1993= \\
100\end{array}$ & $\begin{array}{r}1996= \\
100\end{array}$ & $\begin{array}{r}1993 \\
-99 \\
\end{array}$ & $\begin{array}{r}2000- \\
04\end{array}$ \\
\hline Turkey & 8.4 & 12.9 & 13.8 & 15.5 & 16.6 & 16.8 & 19.1 & 22.3 & 29.9 & 35.4 & 153 & 274 & 11.0 & 19.4 \\
\hline Bulgaria & 1.3 & 2.3 & 2.5 & 2.7 & 2.6 & 3.0 & 3.3 & 3.5 & 4.6 & 5.4 & 178 & 233 & 10.1 & 14.9 \\
\hline Croatia & 2.8 & 3.0 & 2.6 & 2.7 & 2.5 & 2.5 & 2.6 & 2.6 & 3.5 & 4.1 & 107 & 137 & -2.9 & 13.1 \\
\hline Romania & 2.2 & 4.9 & 5.5 & 6.3 & 6.7 & 7.7 & 9.2 & 10.5 & 13.9 & 16.1 & 221 & 325 & 16.8 & 18.9 \\
\hline $\begin{array}{l}\text { Memo: } \\
\text { EU-8 }\end{array}$ & 34.5 & 66.5 & 71.1 & 82.6 & 86.2 & 95.4 & 105.1 & 114.6 & 154.0 & 172.9 & 193 & 260 & 14.3 & 15.7 \\
\hline & \multicolumn{10}{|c|}{ Share in EU25 External Imports (\%) } & & & & \\
\hline Turkey & 1.53 & 1.73 & 1.79 & 1.97 & 2.02 & 1.80 & 2.08 & 2.44 & 2.70 & 2.88 & 113 & 166 & 4.6 & 11.9 \\
\hline Bulgaria & 0.24 & 0.31 & 0.33 & 0.35 & 0.31 & 0.32 & 0.36 & 0.38 & 0.42 & 0.44 & 131 & 141 & 3.7 & 7.5 \\
\hline Croatia & 0.51 & 0.40 & 0.34 & 0.34 & 0.31 & 0.27 & 0.28 & 0.29 & 0.32 & 0.34 & 79 & 83 & -9.4 & 5.7 \\
\hline Romania & 0.41 & 0.66 & 0.71 & 0.80 & 0.82 & 0.83 & 0.99 & 1.15 & 1.26 & 1.31 & 163 & 197 & 10.3 & 11.5 \\
\hline $\begin{array}{l}\text { Memo: } \\
\text { EU-8 }\end{array}$ & 6.28 & 8.92 & 9.19 & 10.49 & 10.49 & 10.24 & 11.42 & 12.53 & 13.88 & 14.07 & 142 & 158 & 7.8 & 8.3 \\
\hline
\end{tabular}

Source: Based on EU as reporter from UN COMTRADE Statistics.

Figure 5: Change in shares in EU external imports in 1992-2004 (1996=100)

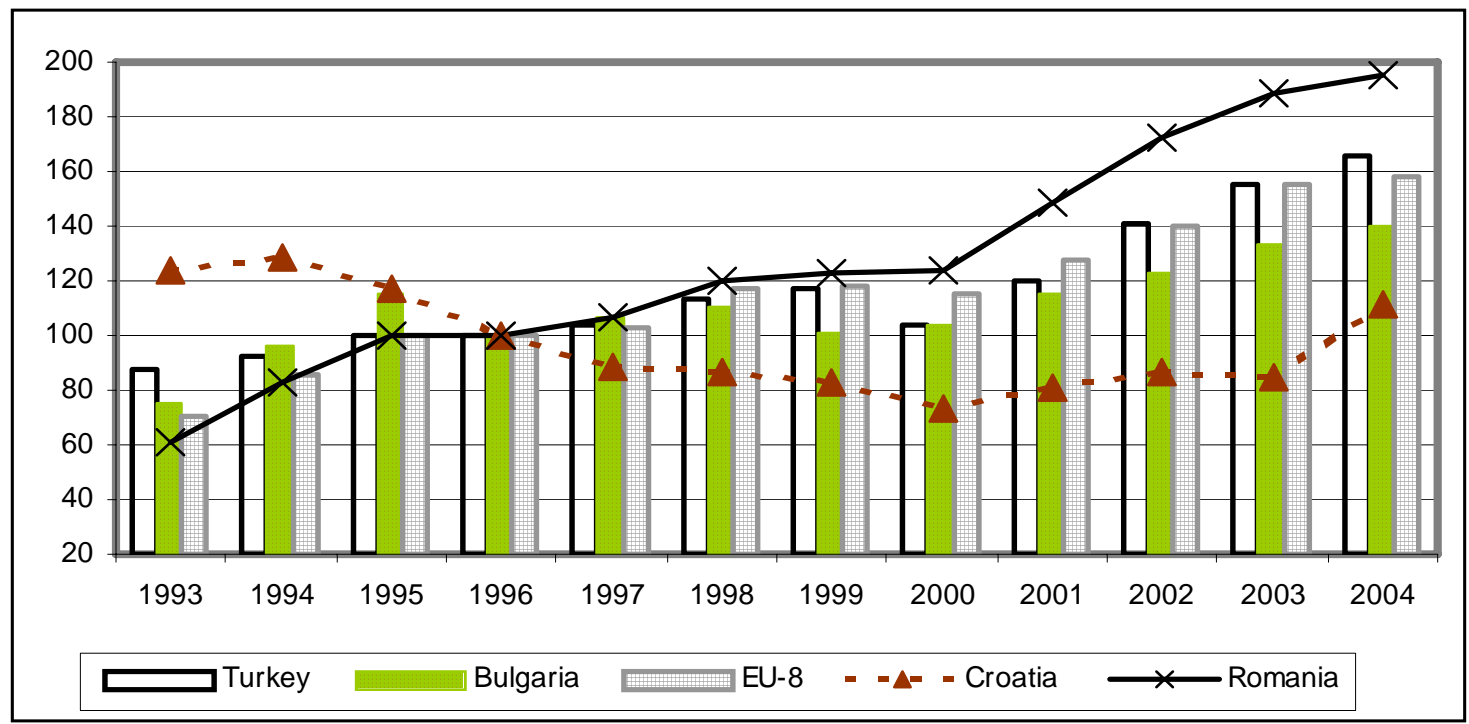

Source: As in Table 7.

Second, once extraordinary factors accountable for the trade performance of former Centrally Planned economies waned away, Turkey emerged in 2000-04 as one of the top export performers even taking as the base Turkey's share in EU external imports in 1999 (2.03 percent) instead of a depressed one in 2000. This would lower its growth rate of the share from 14 percent to still respectable 9 percent per year as compared with 10 percent for EU-8.

Hence, the time profile of changes in Turkey's share in EU import demand in 1996-2004 does not set it apart from other EU Eastern Enlargement countries except for two outliers- 
Bulgaria and Romania. The former stands out because of a weaker performance, whereas the latter due to a stronger performance throughout the whole period. They experienced slow down in 1998-99 (Turkey also a contraction in 2000) and subsequently impressive expansion (Figure 5). The increase in Turkey's share by 10 percent in 2003 over 2002 was larger than for the EU-8 and Romania-both 9 percent.

Similarities between the aggregate performance of the EU-8, which in terms of population roughly equals Turkey's, and Turkey go beyond the time profile over 1996-2003. The factors accountable for the improvement in their export performance in EU markets have been also similar. One may distinguish three factors accountable for change in exports-import demand, competitiveness and diversification. When a country merely maintains its share in imports, the increase in exports is to the growth in import demand. When it increases more than import demand, then these extra exports can be attributable to increased competitiveness. When the increase comes from new exports, it is due to the diversification effect. Table 8 presents the results of calculations of factors of growth in EU-15 oriented exports of EU Eastern Enlargement countries in 2000-04 using four-digit SITC data for EU imports. For each four-digit SITC sector, the shares of regional suppliers in EU imports are calculated for 2000 and 2004. The growth in import demand was accountable for 52 percent of the increase in Turkish exports between 2000 and 2004, the growth in competitiveness for 48 percent of the increase, and the growth in diversification for 1 percent of the increase in exports. Decomposed factors accountable for the expansion of Turkey's EU-15-oriented exports are very similar to those explaining the growth in exports from the EU-8 economies. Except for Croatia, other countries have capitalized not only on the EU-15 demand for exports due to income growth but also succeeded in exploiting costeffective advantages.

Table 8: Sources of growth in EU-oriented exports in regional perspective in 2000-04

\begin{tabular}{|c|c|c|c|c|c|c|c|c|}
\hline \multirow[b]{2}{*}{ Exporter } & \multicolumn{3}{|c|}{ Exports (\$ million) } & \multicolumn{3}{|c|}{ Source of Change (\%) } & \multicolumn{2}{|c|}{ Share in Total Exports } \\
\hline & 2000 & 2004 & \begin{tabular}{|r|} 
Change in \\
$2000-04$
\end{tabular} & Demand & $\begin{array}{r}\text { Competi- } \\
\text { tiveness }\end{array}$ & $\begin{array}{r}\text { Diversif- } \\
\text { ication }\end{array}$ & $\begin{array}{r}(\%) \\
2000\end{array}$ & $\begin{array}{r}(\%) \\
2004\end{array}$ \\
\hline Bulgaria & 2,834 & 5,066 & 2,232 & 38 & 58 & 4 & 1.8 & 1.8 \\
\hline Croatia & 1,910 & 3,315 & 1,405 & 66 & 7 & 27 & 1.2 & 1.2 \\
\hline Romania & 7,134 & 15,138 & 8,004 & 37 & 62 & 2 & 4.5 & 5.3 \\
\hline Turkey & 16,220 & 33,353 & 17,133 & 52 & 48 & 1 & 10.3 & 11.6 \\
\hline EU-8 & 80,521 & 145,765 & 65,243 & 53 & 46 & 1 & 51.3 & 50.7 \\
\hline $\begin{array}{l}\text { Total above } \\
\text { Memo: }\end{array}$ & 108,619 & 202,636 & 94,017 & 51 & 47 & 2 & 69.1 & 70.5 \\
\hline All ECA Countries & 157,082 & 287,317 & 130,235 & 44 & 58 & -2 & 100.0 & 100.0 \\
\hline
\end{tabular}

Note: In addition to EU Eastern Enlargement countries, ECA includes South Eastern Europe (Albania, Bosnia and Herzegovina, Macedonia, Serbia and Montenegro) and CIS (Commonwealth of Independent States) economies (Armenia, Azerbaijan, Belarus, Georgia, Kazakhstan, Kyrgyz Republic, Moldova, Russia Tajikistan, Turkmenistan, Ukraine, and Uzbekistan).

Source: Computations based on UN COMTRADE Statistics with the EU as a reporter.

Turkey's export performance in EU markets also stands out against other European and Central Asian countries. While the share of Bulgaria and Croatia in total EU-oriented exports from the European and Central Asian region remained stable, those of Romania, Turkey and EU8 significantly increased demonstrating superior performance vis-à-vis CIS economies. Turkey's share grew from 10 percent to 12 percent in 2000-04. Overall, the share of EU Eastern Enlargement economies increased from 69.3 percent in 2000 to 70.5 percent in 2004.

\section{F. Concluding observations}

The analysis provides empirical support to the following observations. First, thanks to steady expansion of trade in goods and services since the mid-1980s, Turkey has become highly 
integrated into the world economy. While exports have steadily expanded demonstrating relative insensitiveness to balance of payments crises, imports have been volatile, with their annual changes highly correlated with GDP growth rates. Relative to its geographical location, i.e., distance from major world markets, the level of GDP per capita and its size, Turkey 'overtrades' with the world. Its actual trade is higher than predicted by the regression model and its magnitude in line with 'over-trading' of the EU-8 taken as aggregate.

Second, although Turkey's geographical concentration of trade has increased since the mid-1980s, its pattern remains relatively diversified with significant shares of Middle East and North African countries and NAFTA. The increase in concentration was the result of expanding trade with the EU and stagnation in Middle East and North African trade, which took place in 1985-90. The share of the EU-15 increased from 40 percent in 1985 to 48 percent in 1990. Subsequently, it remained stable at around 47-50 percent of Turkey's total trade turnover. So did it in trade with MENA at around 12 percent of the total, after its share fell from 36 percent to 17 percent over the same period of time.

Third, Turkey's export performance in 1996-2004 in EU markets bears strong similarities to aggregate performance of EU-8 but not to other EU candidate countries. It was much better than that of Bulgaria or Croatia but not as dynamic as that of Romania. While because of earlier 'trade repressive' membership in the CMEA or the former Soviet Union, trade reorientation and the dynamics of catching up with levels determined by economic rather than political considerations were responsible for the surge in EU-destined exports of EU-8 in 1993-96, the differences in respective performance disappeared in 1997-2004 with Turkish exports displaying strong growth in 2001-03. Furthermore, similar factors drove their export expansion with the improved competitiveness in EU markets accounting for almost half of the increase in exports.

\section{Changing patterns of specialization: degree of processing, technological level and factor intensities}

Industrial products have driven export expansion in 1996-2003. Their share in total exports rose from 80 percent in 1995-96 to 85 percent in 2000-01 and 88 percent in 2003-03. This share in Turkish exports to Pan-European free trade area for industrial products, which took 61 percent of Turkish industrial exports, was 90 percent in 2003 up from 81 percent in 1995. Industrial products are a highly heterogeneous group, which raises several questions. What products drove the expansion? What do the changes in exports depending on the degree of processing embodied in exported products tell us about Turkey's industrial capacities? What is the level of technology embodied in imported and exported products? What characteristics do new star performers embody in terms of technology and the degree of processing?

\section{A. Degree of processing in Turkey's trade}

The composition of trade in terms of end-use product categories sheds light on changes in the domestic demand for various goods depending on the extent of their processing as well as a country's capacity to produce more complex products. Both exports and imports may move in similar directions as the capacity to produce more processed goods may require imports of higher processed components. Overall, however, industrial development is associated with the increase in net exports, which can be expressed as percent of their imports, of products representing higher level of processing. A taxonomy of end-use products allows distinguishing between traditional production inputs (foods and feeds together with industrial raw materials) and processed manufactures (machinery together with automobiles and parts). The increase in the weight of the latter in total imports and exports combined with the increase in coverage of these imports by their exports points to the growing level of industrial processing carried out in a country.

Data tabulated in Table 9 indicate a significant increase in the level of processing 
embodied in trade. Consider first that the shares of traditional inputs in Turkey's exports fell from 30 percent in 1990 to 24 percent in 1995, and 13 percent in 2002-04. There was a similar trend in imports, with their share declining from 18 percent in 1995 to 13 percent in 2000-04. While Turkey has been as a rule close to being a net exporter of foods and feeds, industrial materials export coverage of their imports has been falling.

Table 9: Exports and net exports of end-use product categories to Pan-European area and ROW in 1995, 2000-04 (in million of US dollars and percent)

\begin{tabular}{|c|c|c|c|c|c|c|c|c|c|c|c|c|}
\hline \multirow[b]{2}{*}{ Pan-Euro Area } & \multicolumn{5}{|c|}{ Export (\$ million) } & \multicolumn{6}{|c|}{ Export Share (\%) } & \multirow{2}{*}{$\begin{array}{l}\text { LS Growth } \\
2000-04(\%)\end{array}$} \\
\hline & 1995 & 2000 & 2002 & 2003 & 2004 & 1995 & 2000 & 2001 & 2002 & 2003 & 2004 & \\
\hline Agricultural Food \& Feeds & 2,365 & 1,940 & 2,087 & 2,673 & 3,469 & 18.6 & 12.0 & 11.8 & 10.0 & 9.5 & 9.2 & 13.9 \\
\hline Industrial Raw Materials & 359 & 477 & 443 & 591 & 837 & 2.8 & 3.0 & 2.4 & 2.1 & 2.1 & 2.2 & 14.2 \\
\hline Machinery, excl. Auto & 999 & 2,385 & 3,462 & 4,912 & 6,624 & 7.9 & 14.8 & 14.7 & 16.6 & 17.4 & 17.6 & 26.6 \\
\hline Automobiles \& Parts & 444 & 1,013 & 2,290 & 3,711 & 6,427 & 3.5 & 6.3 & 9.5 & 11.0 & 13.1 & 17.0 & 44.7 \\
\hline Textiles \& Clothing & 6,284 & 7,089 & 8,412 & 10,621 & 12,187 & 49.5 & 43.9 & 40.9 & 40.3 & 37.6 & 32.3 & 14.5 \\
\hline Other Consumer Goods & 1,993 & 3,065 & 3,866 & 5,419 & 7,715 & 15.7 & 19.0 & 19.3 & 18.5 & 19.2 & 20.5 & 22.9 \\
\hline Fuels & 250 & 173 & 325 & 326 & 436 & 2.0 & 1.1 & 1.4 & 1.6 & 1.2 & 1.2 & 20.9 \\
\hline All Goods & 12,695 & 16,141 & 20,886 & 28,255 & 37,694 & 100 & 100 & 100 & 100 & 100 & 100 & 21.4 \\
\hline \multicolumn{13}{|l|}{ ROW } \\
\hline Agricultural Food \& Feeds & 2,173 & 1,887 & 1,873 & 2,567 & 3,009 & 24.4 & 16.6 & 16.7 & 12.6 & 13.5 & 11.8 & 10.8 \\
\hline Industrial Raw Materials & 355 & 347 & 348 & 439 & 628 & 4.0 & 3.1 & 2.6 & 2.3 & 2.3 & 2.5 & 14.1 \\
\hline Machinery, excl. Auto & 615 & 1,709 & 1,879 & 2,472 & 3,465 & 6.9 & 15.1 & 15.9 & 12.6 & 13.0 & 13.6 & 15.7 \\
\hline Automobiles \& Parts & 282 & 533 & 979 & 1,419 & 1,726 & 3.2 & 4.7 & 4.5 & 6.6 & 7.5 & 6.8 & 32.1 \\
\hline Textiles \& Clothing & 2,360 & 3,116 & 3,889 & 4,605 & 5,436 & 26.5 & 27.5 & 24.2 & 26.1 & 24.2 & 21.4 & 14.7 \\
\hline Other Consumer Goods & 3,078 & 3,629 & 5,547 & 6,838 & 10,164 & 34.6 & 32.0 & 34.7 & 37.3 & 36.0 & 40.0 & 24.6 \\
\hline Fuels & 40 & 124 & 362 & 659 & 999 & 0.5 & 1.1 & 1.4 & 2.4 & 3.5 & 3.9 & 54.1 \\
\hline All Goods & 8,904 & 11,344 & 14,876 & 18,998 & 25,426 & 100 & 100 & 100 & 100 & 100 & 100 & 19.7 \\
\hline Pan-Euro Area & \multicolumn{5}{|c|}{ Exports in percent of Imports } & \multicolumn{6}{|c|}{$\begin{array}{l}\text { Memo Items: } \\
\text { Total Exports in percent of Imports }\end{array}$} & $\begin{array}{l}\text { LS Growth } \\
\text { All Exports }\end{array}$ \\
\hline Agricultural Food \& Feeds & 139 & 148 & 147 & 153 & 172 & 102 & 93 & 142 & 101 & 101 & 108 & 12.4 \\
\hline Industrial Raw Materials & 29 & 58 & 43 & 35 & 39 & 34 & 38 & 52 & 32 & 28 & 25 & 14.1 \\
\hline Mach & 15 & 24 & 37 & 44 & 44 & 16 & 27 & 44 & 40 & 46 & 43 & 22.4 \\
\hline Automobiles \& Parts & 39 & 22 & 115 & 80 & 76 & 48 & 29 & 127 & 142 & 96 & 81 & 41.2 \\
\hline Textiles \& Clothing & 927 & 584 & 584 & 633 & 642 & 459 & 423 & 485 & 389 & 388 & 361 & 14.5 \\
\hline Other Consumer Goods & 27 & 29 & 32 & 32 & 36 & 46 & 43 & 60 & 55 & 52 & 55 & 23.8 \\
\hline Fuels & 92 & 17 & 48 & 34 & 41 & 6 & 3 & 5 & 8 & 8 & 10 & 39.4 \\
\hline All Goods & 67 & 55 & 74 & 73 & 72 & 60 & 51 & 76 & 70 & 68 & 65 & 20.7 \\
\hline ROW & & & & & & \multicolumn{6}{|c|}{ Pan-Euro Shares in World Exports } & All Imports \\
\hline Agricultural Food \& Feeds & 78 & 68 & 74 & 74 & 76 & 52 & 51 & 49 & 53 & 51 & 54 & 12.9 \\
\hline Industrial Raw Materials & 41 & 26 & 24 & 22 & 17 & 50 & 58 & 56 & 56 & 57 & 57 & 28.7 \\
\hline nery, excl. Auto & 18 & 35 & 49 & 50 & 40 & 62 & 58 & 56 & 65 & 67 & 66 & 13.1 \\
\hline Automobiles \& Parts & 74 & 62 & 325 & 199 & 101 & 61 & 66 & 74 & 70 & 72 & 79 & 23.2 \\
\hline Textiles \& Clothing & 196 & 260 & 225 & 205 & 182 & 73 & 69 & 70 & 68 & 70 & 69 & 19.9 \\
\hline Other Consumer Goods & 82 & 71 & 112 & 102 & 91 & 39 & 46 & 43 & 41 & 44 & 43 & 20.3 \\
\hline Fuels & 0.9 & 1.5 & 4.3 & 6.2 & 7.4 & 86 & 58 & 57 & 47 & 33 & 30 & 11.6 \\
\hline All Goods & 53 & 46 & 64 & 62 & 56 & 59 & 59 & 58 & 58 & 60 & 60 & 16.9 \\
\hline
\end{tabular}

Note: End-Use categories are defined as Agricultural Food \& Feeds (SITC 0+1+2+4-27-28), Industrial Raw Materials (SITC 27+28+68), Machinery, excluding auto (SITC 7-78), Automobiles \& Parts (SITC 78), Textiles $\&$ Clothing (SITC 5+84), other Consumer Goods (SITC 5+6+8+9-65-68-84), Fuels (SITC 3) and All Goods (SITC 0 to 9).

Source: Based on UN COMTRADE Statistics.

Second, exports of capital and transportation equipment and automobile parts have dramatically expanded while their imports have kept up with the overall growth of total imports. Their aggregate share in total exports increased from 7 percent in 1990 to 11 percent in 1995, 21 percent in 2000 and 29 percent in 2004. Exports of machinery had a least square growth rate of 27 percent and of automobiles and parts of 45 percent in 2000-04. Turkey was a net exporter of automobiles and parts in 2001 and 2002 mainly due to the fall in import demand due to a strong depreciation of Turkish lira following the balance of payments crisis in 2001. The value of imports of automobiles and parts fell 54 percent in 2001 and was still 42 percent below its 2000 
level in 2002. In 2003, the value of imports exceeded by 21 percent the 2000 level mainly due to the surge in imports of trucks and tractors. But it rose 89 percent in 2004, with the value of exports also increasing 39 percent. The crisis also affected imports of automobile parts ${ }^{4}$. Since this had no impact on exports automobiles and parts, which boomed in 2001-04, the contraction was short-termed mainly due to the falling domestic demand triggered by the crisis in 2001 .

Third, the expansion in exports of more processed goods took place in highly demanding and competitive Pan-European markets. Traditional industrial inputs accounted for a larger share in ROW-oriented exports (14 percent) than in pan-European exports (11 percent) in 2004. On the other hand, the aggregate share of machinery and automobiles and parts in Pan-Europeandestined exports of 35 percent up from 30 percent a year earlier was below that of 21 percent up from 19 percent in 2003 in ROW exports. The difference is almost exclusively due to much larger Pan-European-oriented exports of automobiles and parts indicating Turkey's participation in EUcentered automotive networks. Pan-European countries took 79 percent of Turkey's exports of automobiles and parts and 66 percent of exports of machinery-these compare favorably with the share of Pan-European area of 60 percent in total Turkish exports.

The compositions of imports by end-use from Pan-European countries and ROW indicates Turkey's growing integration into Pan-European markets based on trade in more processed industrial products. Imports from the Pan-European free trade area for industrial products are much more processed, with fuels, agricultural foods and feeds and industrial raw materials accounting for 10 percent. In contrast, this share in Turkey's imports from ROW is more than four times as large. ${ }^{5}$ Moreover, the gap appears to be growing. But ROW suppliers seem to have retained their competitive edge in Turkey's markets for machinery and capital equipment excluding transportation. ${ }^{6}$

The falling share of machinery in Turkey's total imports suggests weaker investment activity than in the past, which, in turn, may undermine future export growth. The value of their imports was in 2003 merely eight percent above the level in 2000. But they strongly rebounded in 2004 increasing 46 percent, and stood at 158 of their 2000 level. Furthermore, the share of machinery increased in 2004 and accounted on average for one-fourth of total imports in 200004 - still a respectable level by international standards. ${ }^{7}$

\section{B. 'Technology content' of Turkey's trade with the EU and competitiveness}

In order to assess the 'technology content' of Turkey's trade with the EU, we use a simple taxonomy developed by Landesman and Stehrer (2003). It distinguishes among three categories of activities and assign to each of them products identified in trade statistics in terms of two-digit Standard International Trade Classification (SITC. Rev. 3). These categories are low technology and unskilled labor intensive activities, medium to high technology activities and resource intensive activities. The latter cover either extraction of mineral resources or unprocessed agricultural products. Low and labor intensive group includes textiles and clothing, wood products, most chemicals, tires, etc. The medium to high technology group includes machinery and equipment, transport equipment, electrical and optical equipment, pharmaceuticals, etc.

\footnotetext{
4 The contraction in imports of parts was smaller-they fell 41 percent in 2001; in 2002, they were 26 percent below the 2000 level and 20 percent above in 2003.

${ }^{5}$ Between 1990 and 2003 it varied between 43 percent in 2003 and 48 percent in 1990.

${ }^{6}$ Their share in Turkey's imports of these products has been stable at around 30 percent since 1985.

7 This is roughly line with the share of machinery in imports of EU-8 economies but above that for Bulgaria, which was around 20 percent on average in 200-03.
} 
As can be readily seen from Table 10, which presents Turkey's exports and imports in terms of technological and resource intensity, the most visible change in Turkey's EU-oriented exports has been a dramatic shift towards medium and high technology products. The value of their exports increased eight-fold between 1995 and 2004 growing at an average rate of 21.5 percent over 1995-2003. The average rate of growth for low tech and unskilled labor intensive products was 5.4 percent and that for resource intensive products amounted to 9.9 percent.. If these growth rates continue over 2004-05, the value of exports of medium and high technology products will exceed that of low tech and labor intensive products by the end of 2005. The share of medium to high tech products rose from 13 percent in 1995 to 25 percent in 2000 and 37 percent in 2004. The growth in exports was not solely the result of expanding EU import demand for these products but also of stronger competitiveness of Turkish suppliers. They increased their share in EU external imports of these products from 0.6 percent in 1995 to 0.9 percent in 2000, 2.1 percent in 2003 and to 2.5 percent in 2004.

Table 10: "Technology content" of trade with EU-25 and patterns of specialization in 1996, 2000-2004 (in million of US dollars and percent)

\begin{tabular}{|c|c|c|c|c|c|c|c|c|}
\hline \multirow[b]{2}{*}{ Factor Input } & & & & & & \multirow{2}{*}{2004} & \multicolumn{2}{|c|}{ Index 2004} \\
\hline & 1995 & 2000 & 2001 & 2002 & 2003 & & \multicolumn{2}{|c|}{$1995=1002000=100$} \\
\hline \multicolumn{3}{|c|}{\begin{tabular}{|l} 
Turkey's Exports to EU25 (\$ million) \\
\end{tabular}} & & & & & & \\
\hline Low tech products \& labor intensive & 8,459 & 9,552 & $\overline{10,361}$ & 11,630 & 14,805 & 16,422 & 194 & 172 \\
\hline Medium to high tech products & 1,623 & 4,112 & 5,325 & 7,041 & 10,297 & 13,157 & 810 & 320 \\
\hline Resource intensive products & 2,078 & 3,087 & 3,398 & 3,579 & 4,729 & 5,708 & 275 & 185 \\
\hline \multicolumn{9}{|c|}{ Turkey's Export Share (\%) } \\
\hline Low tech products \& labor intensive & 69.6 & 57.0 & 54.3 & 52.3 & 49.6 & 46.5 & 67 & 82 \\
\hline Medium to high tech products & 13.3 & 24.5 & 27.9 & 31.6 & 34.5 & 37.3 & 279 & 152 \\
\hline Resource intensive products & 17.1 & 18.4 & 17.8 & 16.1 & 15.9 & 16.2 & 95 & 88 \\
\hline \multicolumn{9}{|c|}{ Exports in percent of Imports (\%) } \\
\hline Low tech products \& labor intensive & 402 & 430 & 546 & 479 & 510 & 507 & 126 & 118 \\
\hline Medium to high tech products & 20 & 26 & 59 & 62 & 60 & 56 & 280 & 217 \\
\hline Resource intensive products & 36 & 38 & 53 & 43 & 41 & 40 & 111 & 105 \\
\hline \multicolumn{9}{|c|}{ Share in EU25 External Imports (\%) } \\
\hline Low tech products \& labor intensive & 5.9 & 6.5 & 6.8 & 7.3 & 7.8 & 8.3 & 142 & 129 \\
\hline Medium to high tech products & 0.5 & 0.9 & 1.3 & 1.7 & 2.1 & 2.5 & 453 & 262 \\
\hline Resource intensive products & 0.8 & 0.9 & 1.0 & 1.1 & 1.2 & 1.2 & 151 & 132 \\
\hline \multicolumn{9}{|c|}{ Export Specialization Index } \\
\hline Low tech products \& labor inten & 3.4 & 3.5 & 3.2 & 2.9 & 2.8 & 2.8 & 84 & 80 \\
\hline Medium to high tech products & 0.3 & 0.5 & 0.6 & 0.7 & 0.8 & 0.8 & 268 & 162 \\
\hline Resource intensive products & 0.5 & 0.5 & 0.5 & 0.4 & 0.4 & 0.4 & 89 & 82 \\
\hline
\end{tabular}

Source: Computations based on EU25 data from UN COMTRADE Statistics.

Yet, low technology and unskilled labor intensive products still remain Turkey's major specialization in EU markets. Turkey has a very strong revealed export specialization in EU markets for these products. The value of Export Specialization Index (ESI-ratio of their share in Turkish EU-oriented exports to their share in EU total external imports) is well below unity, ${ }^{8}$ albeit it has been declining. Turkish suppliers have a significant and growing presence in these markets. Turkish exports accounted for 8 percent of EU total imports of low tech and unskilled labor intensive products in 2003. Furthermore, Turkish exporters have been consistently outperforming other competitors, as their share in EU external imports of these products has been

${ }^{8}$ The export specialization index $\left(\mathrm{ES}_{\mathrm{ij}}\right)$ for a product $j$ of country $i$, is specified here as follows: $E S_{\mathrm{ij}}=$ $\left(\mathrm{x}_{\mathrm{ij}} / \mathrm{Xi}\right) /\left(\mathrm{m}_{\mathrm{j}} / \mathrm{M}\right)$, where: $\mathrm{x}_{\mathrm{ij}}$ is country i's exports of product $\mathrm{j}$ to the $E U ; \mathrm{X}_{\mathrm{i}}=\Sigma \mathrm{j} \mathrm{x}_{\mathrm{ij}}$ is country i's total exports to the EU; $M_{j}=\Sigma j x_{i j}$ is EU's total 'external' imports of a product $j ; M=\Sigma i ~ \sum j x_{i j}$ is EU's total external imports. A value for this index below unity indicates a comparative disadvantage. If the index takes a value greater than unity, the country is considered to have a "revealed" comparative advantage in the product. In this particular case, Turkey has a revealed comparative advantage in a product if its export of that item as a share of its total exports exceeds the EU imports of the item as a share of EU total imports. 
steadily rising since 1995 .

Low technology and unskilled labor intensive products are also Turkey's major source of net foreign currency earnings. Turkey is a huge net exporter of low technology and labor intensive products to the EU and net importer of medium to high tech products. Its exports of the former have been around five times higher in terms of value than imports from the EU generating export earnings to finance other imports. While Turkey is a large net importer of medium to high value products, their exports in terms of their imports significantly increased from 20 percent in 1995 to 26 percent in 2000, 59 percent in 2001 and slightly fell to 56 percent in 2004. So did the imports. They were around three times higher in 2004 than in 1995.

Relative stability of the time profile of 'technology content' of Turkey's imports from the EU contrasts rather sharply with changes in 'technology content' of Turkish exports to these markets. Figure 6 presents respective shares of exports and imports from the EU in total 'tech' exports and imports excluding resource intensive products. The change in Turkish EU-oriented exports was very extensive, with the share of low tech and unskilled labor intensive products falling steadily from 90 percent in 1990 to 70 percent in 2000 and 56 percent in 2004. Over 19902004, the share of 'low tech and unskilled labor intensive' products in Turkish imports from the EU oscillated between 13 percent (2000) and 20 percent (1995) and high and medium tech products between 77 percent and 80 percent.

Figure 6: 'Technology content' of Turkish trade with the EU in 1990-2004 (in percent)

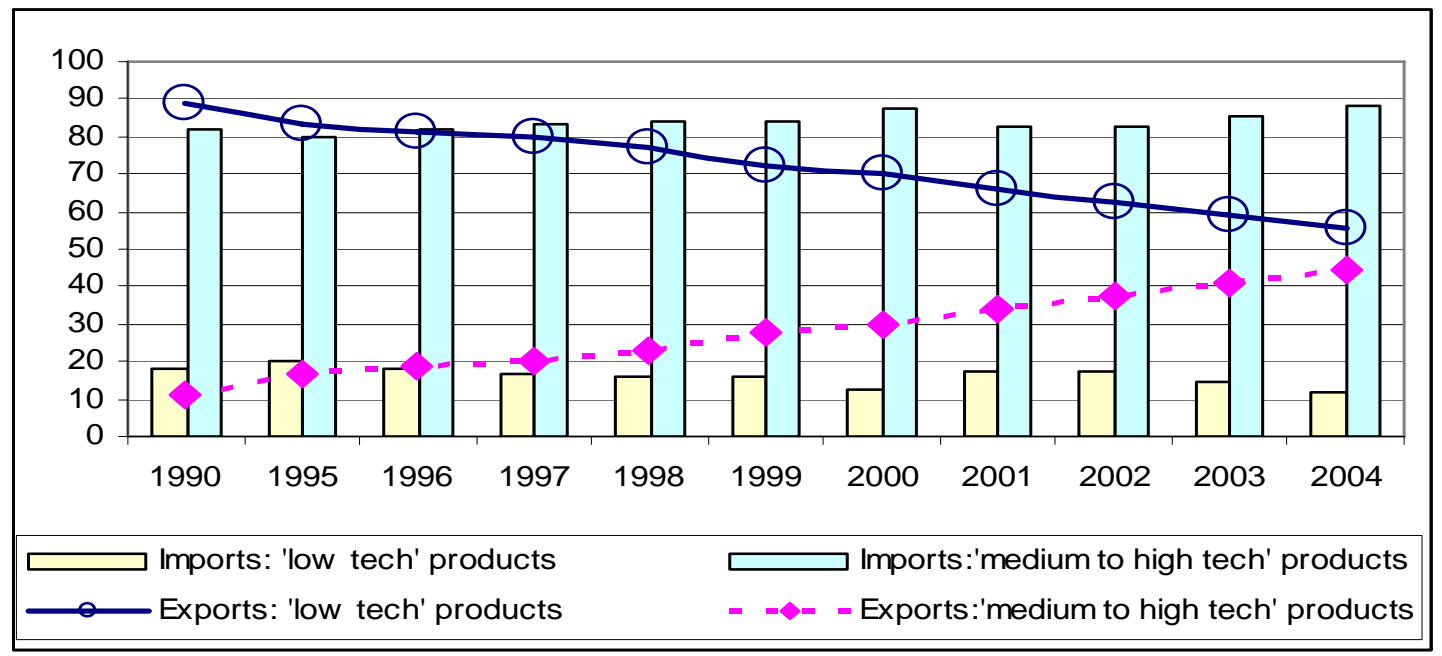

Source: Computations based on EU25 data from UN COMTRADE Statistics.

Hence, since around 1998 there has been a very strong shift towards products characterized by medium to high technology processes. Since exports of resource intensive products expanded broadly in line with total exports, the growth in the weight of medium to high tech products has been at the expense of low technology products. On the import side, the composition has been stable with medium to high technology products accounting for most of Turkey's imports from the EU.

EU markets have played a critical role in transformation of Turkish export basket. Table 11 listing 20 top sectors, identified in terms of four-digit SITC products, ranked according to the value of exports to the EU (Table 11) provides a good illustration of it. ${ }^{9}$ These sectors drove the

\footnotetext{
${ }^{9}$ Sectors successful in global markets have also been successful in EU markets. Annex Table 1 provides the list of top twenty sectors in terms of the size of their worldwide exports. It is the same for total exports and EU-destined exports.
} 
transformation, with their share in Turkish EU-destined exports increasing from 47 percent in 2000 to 56 percent in 2004. Furthermore, the shares of exports to the EU of Turkey's top 20 exporters (71 percent) tend to be much higher than the average share of the EU in total exports (60 percent). Leaving aside clothing, this applies in particular to technologically more sophisticated sectors exporting automotive parts, electronics, etc. EU markets take 91 percent of motor vehicles for transport of goods, 90 percent of Turkey's exports of television receivers and 80 percent of parts of piston engines. Exports of household refrigerators, whose value of exports increased 2.7 times, expanded more to other markets following their success in EU markets, whose share fell from 80 percent in 2000 to 73 percent in 2003. The same pattern can be observed in the case of passenger motor cars.

Table 11: Top twenty four-digit SITC exporters to the EU in 2004: exports, ranking, share in total and percentage of exports going to the EU in 2000 and 2004 (in percent and millions of US dollars)

\begin{tabular}{|c|c|c|c|c|c|c|c|c|c|c|}
\hline \multirow[b]{2}{*}{ SITC4 } & \multirow[b]{2}{*}{ Product } & \multicolumn{2}{|c|}{$\begin{array}{l}\text { Exports (\$ } \\
\text { million) }\end{array}$} & \multirow{2}{*}{$\begin{array}{c}2004 \\
\text { Index } \\
2000=100 \\
\end{array}$} & \multicolumn{2}{|c|}{ Export share } & \multicolumn{2}{|c|}{ Ranking } & \multicolumn{2}{|c|}{$\begin{array}{l}\text { Share of EU } \\
\text { in Exports }\end{array}$} \\
\hline & & 2000 & 2004 & & 2000 & 2004 & 2000 & 2004 & 2000 & 2004 \\
\hline 7810 & $\begin{array}{l}\text { Passenger motor cars, for } \\
\text { transport }\end{array}$ & 491 & 2,838 & 578 & 2.9 & 8.0 & 6 & 1 & 84 & 76 \\
\hline 8462 & $\begin{array}{l}\text { Under garments, knitted of } \\
\text { cotton }\end{array}$ & 1,046 & 2,351 & 225 & 6.2 & 6.6 & 1 & 2 & 72 & 82 \\
\hline 7611 & $\begin{array}{l}\text { Television receivers } \\
\text { Motor vehicles for }\end{array}$ & 768 & 1,971 & 256 & 4.6 & 5.6 & 3 & 3 & 90 & 91 \\
\hline 7821 & transport of goods & 37 & 1,484 & 4,022 & 0.2 & 4.2 & 84 & 4 & 78 & 89 \\
\hline 8439 & $\begin{array}{l}\text { Other outer garments } \\
\text { Jerseys, pull-overs, }\end{array}$ & 729 & 1,399 & 192 & 4.3 & 4.0 & 4 & 5 & 64 & 73 \\
\hline 8451 & $\begin{array}{l}\text { twinsets, cardigans } \\
\text { Other outer garments \& }\end{array}$ & 870 & 1,155 & 133 & 5.2 & 3.3 & 2 & 6 & 83 & 79 \\
\hline 8459 & $\begin{array}{l}\text { clothing } \\
\text { Other parts \& accessories }\end{array}$ & 593 & 1,111 & 187 & 3.5 & 3.1 & 5 & 7 & 73 & 75 \\
\hline 7849 & $\begin{array}{l}\text { of motor vehicles } \\
\text { Bed linen, table linen, toilet }\end{array}$ & 379 & 1,044 & 276 & 2.3 & 3.0 & 9 & 8 & 62 & 64 \\
\hline 6584 & $\begin{array}{l}\text { \& kitchen } \\
\text { Trousers, breeches etc. of }\end{array}$ & 461 & 888 & 193 & 2.7 & 2.5 & 7 & 9 & 74 & 66 \\
\hline 8423 & textile fabrics & 431 & 747 & 173 & 2.6 & 2.1 & 8 & 10 & 71 & 66 \\
\hline 8472 & $\begin{array}{l}\text { Clothing accessories } \\
\text { Fruit otherwise prepared }\end{array}$ & 257 & 603 & 235 & 1.5 & 1.7 & 13 & 11 & 92 & 83 \\
\hline 0589 & $\begin{array}{l}\text { or preserved } \\
\text { Parts of internal } \\
\text { combustible piston }\end{array}$ & 203 & 561 & 276 & 1.2 & 1.6 & 19 & 12 & 83 & 83 \\
\hline 7139 & $\begin{array}{l}\text { engines } \\
\text { Under garments, knitted, }\end{array}$ & 189 & 554 & 293 & 1.1 & 1.6 & 20 & 13 & 76 & 77 \\
\hline 8463 & of synthetic & 311 & 538 & 173 & 1.9 & 1.5 & 11 & 14 & 91 & 87 \\
\hline 6732 & Bars \& rods, of iron/steel & 159 & 429 & 270 & 0.9 & 1.2 & 22 & 15 & 20 & 25 \\
\hline 0577 & $\begin{array}{l}\text { Edible nuts } \\
\text { Insulated elect.wire, cable, }\end{array}$ & 375 & 421 & 112 & 2.2 & 1.2 & 10 & 16 & 81 & 78 \\
\hline 7731 & $\begin{array}{l}\text { bars, strings } \\
\text { Household type }\end{array}$ & 278 & 396 & 142 & 1.7 & 1.1 & 12 & 17 & 61 & 49 \\
\hline 7752 & $\begin{array}{l}\text { refrigerators } \\
\text { Public-service type }\end{array}$ & 157 & 395 & 251 & 0.9 & 1.1 & 24 & 18 & 81 & 70 \\
\hline 7831 & $\begin{array}{l}\text { passenger motor } \\
\text { Other tubes and pipes, of }\end{array}$ & 206 & 389 & 189 & 1.2 & 1.1 & 18 & 19 & 21 & 42 \\
\hline \multirow[t]{2}{*}{6783} & iron or steel & 158 & 351 & 223 & 0.9 & 1.0 & 23 & 20 & 63 & 56 \\
\hline & All above products & 8,097 & 19,626 & 242 & 48.2 & 55.5 & & & 69 & 71 \\
\hline 0 to 9 & All goods & 16,803 & 35,378 & 211 & 100 & 100 & & & 55 & 55 \\
\hline
\end{tabular}

Source: Derived from the UN COMTRADE database as reported by the EU.

The composition of exports of top-twenty performers in terms of technology content and natural resource intensity also points to significant realignment in Turkish export offer. The share 
of medium to high technology products in top-twenty rose from 25 percent in 2000 to 39 percent in 2004 almost exclusively at the expense of the fall in the share of low technology products from 59 percent to 47 percent. Spectacular increases in exports of passenger cars and trucks and exports of boats and other vessels have been behind this change.

\section{Transformation in factor intensities of Turkish exports}

Patterns in trade in goods reflect differences in comparative advantage as determined by different factor endowments among countries. A country tends to export those goods that use its factors that are relatively abundant. ${ }^{10}$ Exploring a full causal chain linking factor endowments, comparative advantage and trade patterns are not relevant for this discussion. ${ }^{11}$ The question germane here concerns assessment of broad changes in relative factor intensities as revealed in Turkey's trade with the EU and other Pan-European partners.

Given the differences in respective endowments in factors of production, one would expect Turkey to export products to its Pan-European partners with significant content of natural resource and unskilled labor intensive products and import capital and skilled labor intensive products. Indeed, empirical data corroborate this expectation, but only on the import side. Turkey's imports from the EU have been remarkable stable in terms of content over time, with capital and skilled labor intensive goods accounting for around 80 percent of Turkey's imports.

Like experiences only shared among EU-8 economies, Turkey has witnessed a very significant restructuring in factor intensities of its exports. The factor content of Turkish exports has undergone dramatic change indicating rapid movement towards higher value-added products (see Figure 7). The share of natural resource-based and unskilled labor intensive products has been falling, while that of capital- and skilled labor-intensive products has been rapidly expanding especially over the last four years. Skilled labor intensive products have been the major drivers of change. While in 1990 their share in total EU-oriented exports amounted to 10 percent as compared with 54 percent for unskilled labor-intensive products, the former rose to 22 percent and the latter fell to 49 percent in 2000. In 2004 these shares were 30 percent and 46 percent, respectively.

The shift away from products embodying natural resources and unskilled labor, which is a reflection of the development of more sophisticated industrial capacities competitive in global markets, has been quite significant even when cast against EU-8. The simple average of the aggregate share of skilled labor and capital intensive products in total EU-directed exports from the EU-8 increased 18 percentage points from 51 percent in 1996 to 69 percent in 2004 (Table 12). This share in Turkey's total exports increased 23 percentage points from 21 percent in 1996 to 44 percent in 2004.

\footnotetext{
${ }^{10}$ However, this fully takes place if there is a competitive market mechanism efficiently allocating resources By the same token, the persistence in disconnect between country's endowments in factors of production and factor intensities of its exports point to major institutional and policy deficiencies in the existing economic regime.

${ }^{11}$ The goodness of results obtained hinges critically on the quality of a classification used to examine export baskets over time by factor mix. The choice is always controversial. There are woeful difficulties to define and measure factor intensity, and trade theorists have long wrestled with it. Some definitions of the groups of goods by factor intensity are overlapping and non-exhaustive. Definitions used here do not suffer from these shortcomings--all industries are taken into account and an industry appears only in one classification; and the classification distinguishes among four types of factors. Since some industries are intensive in terms of more than one factor, the results may be distorted. But even assuming that the initial classification captures adequately factor proportions at a given point of time, with the passage of time it may provide a distorted picture. Some industries may become more capital-intensive or less active in technological terms.
} 
Figure 7: Factor intensities of Turkey's exports to the EU in 1990, 1995-2004 (in percent)

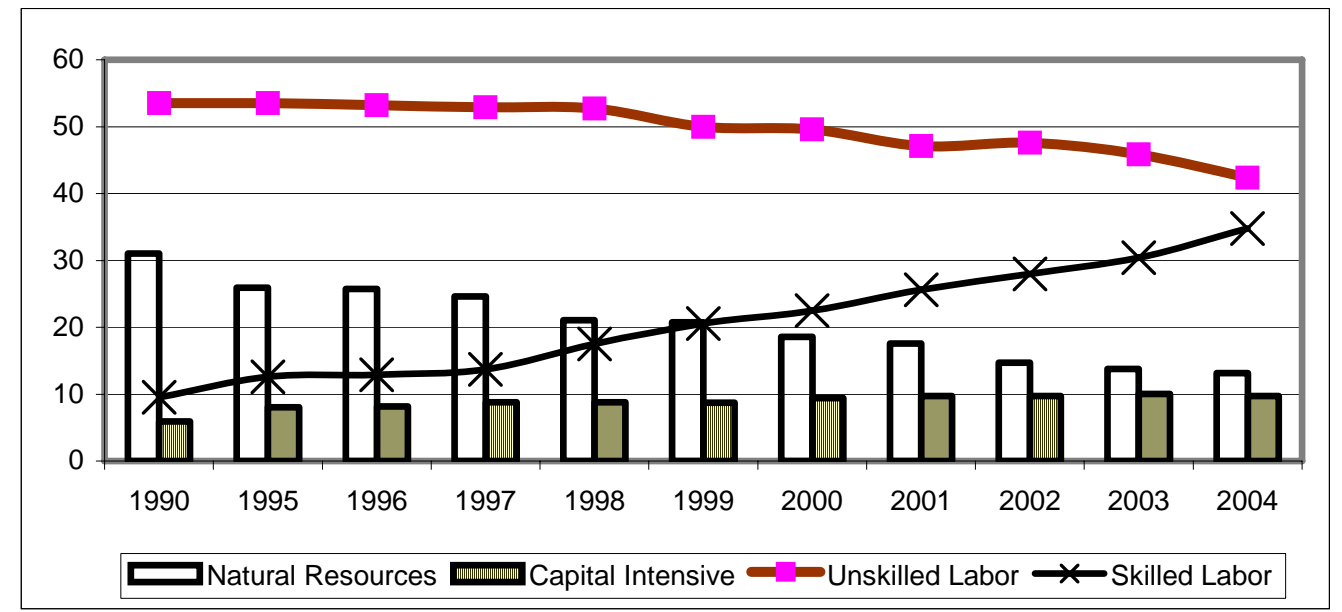

Source: Computations based on EU data from UN COMTRADE Statistics.

Table 12: Share of skilled labor and capital intensive products in total exports of EU candidate countries and EU-8 in 1996 and 2004 (in percent)

\begin{tabular}{|c|c|c|c|c|c|c|}
\hline \multirow[b]{2}{*}{ Country/Group } & \multicolumn{2}{|c|}{1996} & \multicolumn{2}{|c|}{2004} & \multicolumn{2}{|c|}{ Percent Point Change } \\
\hline & $\begin{array}{l}\text { \% Share in } \\
\text { Total Exports }\end{array}$ & $\begin{array}{l}\text { Of which: \% in } \\
\text { Skilled Labor }\end{array}$ & $\begin{array}{l}\text { \% Share in } \\
\text { Total Exports }\end{array}$ & $\begin{array}{l}\text { Of which: \% in } \\
\text { Skilled Labor }\end{array}$ & $\begin{array}{c}\text { \% Share in } \\
\text { Total Exports }\end{array}$ & $\begin{array}{l}\text { Of which: \% in } \\
\text { Skilled Labor }\end{array}$ \\
\hline Turkey & 21 & 13 & 44 & 35 & 23 & 22 \\
\hline Bulgaria & 39 & 15 & 31 & 15 & -7 & 0 \\
\hline Croatia & 33 & 10 & 34 & 11 & 1 & 1 \\
\hline Romania & 29 & 14 & 35 & 16 & 6 & 1 \\
\hline EU-8 (simple average) & 51 & 26 & 69 & 34 & 18 & 9 \\
\hline $\begin{array}{l}\text { Memo: } \\
\text { SEE-4 (simple average) }\end{array}$ & 20 & 10 & 27 & 16 & 7 & 6 \\
\hline
\end{tabular}

Note: SEE-4: Albania, Bosnia and Herzegovina, FYR Macedonia and Serbia and Montenegro

Source: Computations based on EU-15 data as reported in UN COMTRADE Statistics.

Turkey’s performance contrasted rather sharply with that of other EU candidate countries and South East European countries (SEE-4, see note in Table 12), which are parts of the EU Stabilization and Association process. While the aggregate share of skilled labor and capitalintensive products in Turkish exports in 1996 was well below that in other comparator countries and groups except for SEE-4, the share in 2004 was the second largest after the EU-8. Between 1996 and 2004 it increased seven percentage points in exports from SEE-4, six percentage points in Romania's exports and 1 percentage point in Croatia's exports. It fell seven percentage points in Bulgaria's exports triggered by the increase in exports of unskilled labor intensive products rather than natural resource intensive products, as one might expect given Bulgaria's endowments in factors of production. ${ }^{12}$

Another interesting feature of Turkey's performance relative to other European transition economies - except for SEE-4 economies and Croatia — was that the levers of growth were skilled labor intensive products. They were responsible for 96 percent of the increase in the weight of these products in Turkish total exports between 1996 and 2004 as compared to 49 percent for the EU-8 economies and 25 percent for Romania. As for SEE-3 economies and Croatia the increase came also from exports of skilled labor intensive products accounting for 83 percent and 96 percent of the respective changes.

\footnotetext{
12 The share of unskilled labor intensive products in Bulgaria’s exports increased from 17 percent in 1996 to 31 percent in 2004.
} 
Indeed, skilled labor intensive products drove the expansion of Turkish exports in 200004 and were the bright spot in export performance in 1996-2000 that barely kept pace with the growth in Pan-European external import demand. Exports of skilled labor intensive products grew on average (least square average) over 1990-2004 at 21 percent per year, with the growth clearly accelerating towards the end of this period. Least square average growth rates were 12 percent for 1990-95, 22 percent for 1996-2000 and 31 percent for 2000-04. Improvements in competitiveness in Pan-European markets have been responsible for the expansion in exports since 1994. While in 1990-93 the share of skilled labor intensive products imported from Turkey in Pan-European external imports, as well as in EU-15 imports, was stable at around 1 percent, it increased to 1.2 percent in 1994 and kept growing every year in 1995-2004. Leaving aside a very small increase in the share of unskilled labor intensive products in 2000 over 1996 (0.1 percentage point) in Pan-European imports of these products, skilled labor intensive products were the only group that increased its share during this period (Table 13).

A sharp decline in the share of natural resource intensive products in Turkish exports has accompanied rapid growth in skilled labor intensive exports. After a steep decline in 1990-92, the share of natural resource products was stable until 1997. During this period the rise of skilled labor intensive products was at the expense of unskilled labor intensive products whose share fell from 58 percent in 1993 to 52 percent in 1997 (Figure 8).

Capital intensive exports regained their vigor in 2000-03 following a period of relatively uninspiring performance in 1996-99. Their share in Turkey's Pan-European exports stagnated in 1996-99 after significantly expanding in 1990-94 from 6 percent to 9 percent and increased to 9.6 percent in 2000, 10.3 percent in 2003 and slightly fell to 9.7 percent in 2004.

Table 13: Factor content of Turkey's Pan-European exports in 1996-2004 and their dynamics over 1999-2004 (in million of US dollars and percent)

\begin{tabular}{|c|c|c|c|c|c|c|c|c|c|c|c|c|}
\hline \multirow[b]{2}{*}{ Factor Intensity } & \multirow[b]{2}{*}{1996} & \multirow[b]{2}{*}{1997} & \multirow[b]{2}{*}{1998} & \multirow[b]{2}{*}{1999} & \multirow[b]{2}{*}{2000} & \multirow[b]{2}{*}{2001} & \multirow[b]{2}{*}{2002} & \multirow[b]{2}{*}{2003} & \multirow[b]{2}{*}{2004} & \multicolumn{3}{|c|}{ Least Square Growth } \\
\hline & & & & & & & & & & $1990-95$ & $1996-00$ & $2000-04$ \\
\hline & \multicolumn{9}{|c|}{ Turkey's Exports to Pan-Euro (\$ million) } & & & \\
\hline Natural Res. & 3,496 & 3,606 & 3,478 & 3,643 & 3,318 & 3,586 & 3,494 & 4,414 & 4,991 & 3.6 & -0.9 & 10.2 \\
\hline Unskilled Labor & 7,019 & 7,518 & 8,389 & 8,557 & 8,634 & 9,408 & 11,159 & 14,524 & 16,072 & 6.7 & 5.4 & 16.8 \\
\hline Capital & 1,164 & 1,312 & 1,476 & 1,543 & 1,684 & 1,995 & 2,318 & 3,283 & 3,680 & 15.2 & 9.0 & 20.6 \\
\hline Skilled Labor & 1,777 & 1,984 & 2,841 & 3,556 & 3,929 & 5,087 & 6,532 & 9,637 & 13,198 & 11.8 & 21.7 & 30.6 \\
\hline \multirow[t]{3}{*}{ All above goods } & 3,457 & 14,420 & 16,185 & 17,300 & 17,565 & 20,076 & 23,503 & 31,859 & 37,941 & 7.0 & 7.1 & 20.0 \\
\hline & \multirow{2}{*}{\multicolumn{9}{|c|}{ Export Share of Pan-Euro (\%) }} & \multicolumn{3}{|c|}{ Percent Points Change } \\
\hline & & & & & & & & & & \multicolumn{3}{|c|}{$\begin{array}{lll}1990-95 & 1996-00 \quad 2000-04 \\
\end{array}$} \\
\hline Natural Res. & 26.0 & 25.0 & 21.5 & 21.1 & 18.9 & 17.9 & 14.9 & 13.9 & 13.2 & -5.5 & -7.1 & -5.7 \\
\hline Unskilled Labor & 52.2 & 52.1 & 51.8 & 49.5 & 49.2 & 46.9 & 47.5 & 45.6 & 42.4 & -0.6 & -3.0 & -6.8 \\
\hline Capital & 8.6 & 9.1 & 9.1 & 8.9 & 9.6 & 9.9 & 9.9 & 10.3 & 9.7 & 2.5 & 0.9 & 0.1 \\
\hline \multirow[t]{3}{*}{ Skilled Labor } & 13.2 & 13.8 & 17.6 & 20.6 & 22.4 & 25.3 & 27.8 & 30.2 & 34.8 & 3.6 & 9.2 & 12.4 \\
\hline & \multirow{2}{*}{\multicolumn{9}{|c|}{ Share in Pan-Euro External Imports (\%) }} & \multicolumn{3}{|c|}{ Percent Points Change } \\
\hline & & & & & & & & & & $1990-95$ & $1996-00$ & $2000-04$ \\
\hline Natural Res. & 1.5 & 1.5 & 1.7 & 1.7 & 1.2 & 1.4 & 1.4 & 1.4 & 1.5 & 0.2 & -0.2 & 0.2 \\
\hline Unskilled Labor & 8.2 & 8.1 & 8.7 & 8.8 & 8.3 & 9.1 & 10.4 & 11.1 & 11.5 & 1.0 & 0.1 & 3.2 \\
\hline Capital & 0.5 & 0.5 & 0.5 & 0.5 & 0.5 & 0.6 & 0.7 & 0.9 & 0.9 & 0.1 & 0.0 & 0.4 \\
\hline Skilled Labor & 2.0 & 2.1 & 2.7 & 3.3 & 3.6 & 4.9 & 5.9 & 6.9 & 8.1 & 0.8 & 1.6 & 4.5 \\
\hline All above goods & 2.0 & 2.1 & 2.3 & 2.4 & 2.1 & 2.5 & 3.0 & 3.3 & 3.5 & 0.3 & 0.0 & 1.5 \\
\hline
\end{tabular}

Source: Computations based on Pan-European import data from UN COMTRADE Statistics. 
Figure 8: Evolution in the factor content of Turkish Pan-European-destined exports over 19902003(in percent)

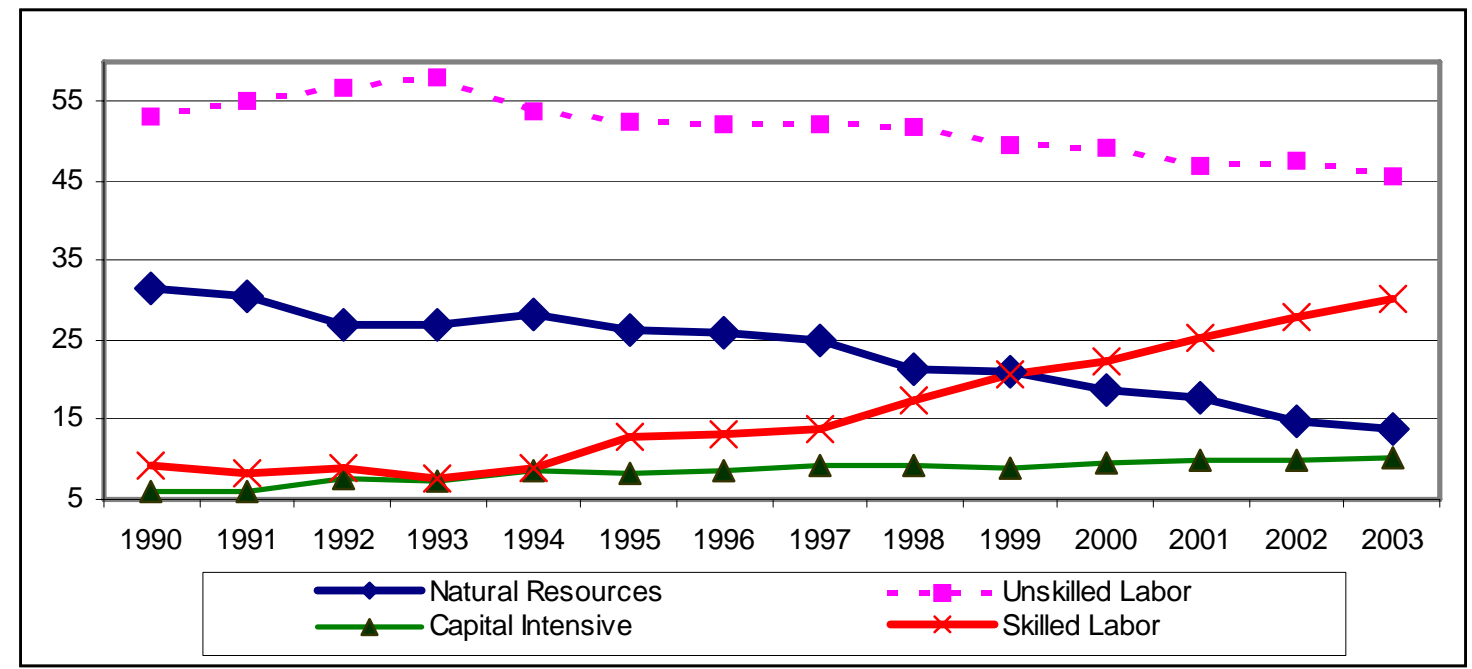

Source: As in Table 13.

Developments in factor intensity of exports point to the growing importance of Turkey's links to EU-8 as well as other Pan-European countries (Bulgaria, Romania and EFTA) aside from the EU-15. Pan-European markets other than those of the EU-15 have become increasingly receptive consumers of skilled labor and capital intensive products made in Turkey and engines of Turkey's export growth. While Turkish exports to these markets have registered a stronger growth than in exports to EU-15 across all categories of products in terms of their factor intensities, growth differentials, however, were particularly large in capital and skilled labor intensive products. The value of exports of these products increased almost four-fold between 2000 and 2004 from US\$ 533 million to US\$ 2,540 million. The growth of these exports was twice as fast as EU-15-destined exports of these products.

Table 14: Developments in exports to non-EU-15 Pan-European economies in 1990, 2000 and 2003 (in percent)

\begin{tabular}{|c|c|c|c|c|c|c|c|c|c|}
\hline \multirow[b]{2}{*}{ Factor Intensity } & \multicolumn{3}{|c|}{ Composition } & \multicolumn{3}{|c|}{ Least Square Growth } & \multicolumn{3}{|c|}{$\begin{array}{l}\text { Non-EU-15 in Turkey's } \\
\text { Pan-Euro Exports }\end{array}$} \\
\hline & 1990 & 1996 & 2004 & $1990-95$ & $1996-00$ & 2000-04 & 1990 & 1996 & 2004 \\
\hline Natural Resource & 49.1 & 35.1 & 13.4 & 6.9 & -0.4 & 17.6 & 6.3 & 9.5 & 13.4 \\
\hline Unskilled Labor & 41.1 & 31.0 & 35.8 & 11.0 & 15.5 & 30.8 & 3.1 & 4.2 & 11.1 \\
\hline Capital & 4.3 & 16.2 & 14.0 & 43.9 & 2.4 & 37.0 & 3.0 & 13.2 & 19.0 \\
\hline Skilled Labor & 5.4 & 17.7 & 36.8 & 36.3 & 21.3 & 41.5 & 2.3 & 9.4 & 14.0 \\
\hline All above goods & 100 & 100 & 100 & 15.0 & 10.1 & 32.7 & 4.0 & 7.0 & 13.2 \\
\hline
\end{tabular}

Source: Computations based on Pan-Euro and EU import data from UN COMTRADE Statistics.

In contrast to export performance in 1990-95, skilled labor intensive products have subsequently become the major levers of export expansion to non-EU-15 Pan-European markets. While capital intensive products followed by skilled labor intensive exports drove the growth in 1990-96, the latter drove the expansion in 1996-2003. The share of EU-15 in Turkish PanEuropean exports of skilled labor products fell from 98 percent in 1990 to 916 percent in 1996 and 86 percent in 2004.

Simultaneously, the factor content gap between EU-15-destined exports and those to other pan-European markets has been falling. While through the 1990s the EU-oriented export basket had a lower presence of natural resources intensive products and a larger presence of 
unskilled labor intensive products, Turkish exports to other pan-European markets in terms of factor intensities began converging in 1999-2004. The difference between shares of natural resources products has become negligible and than between shares of unskilled labor intensive fell from around 20 percentage points in favor of the EU-15 in 1991-1998 to 9 percentage points in 2001-02. ${ }^{13}$ Correspondingly, non-EU-15 pan-European exports had larger shares of capital and skilled labor intensive goods. In contrast, factor content of exports to non-Pan-European markets is different in two respects: it continues to be more natural resource based and less unskilled labor intensive.

But even more significant is that the difference between respective export baskets in 2004 is incomparably smaller than it was in 1996-98 indicating growing similarity in Turkey's specialization patterns in Pan-European and other markets. While the share of natural resourcebased products has been falling in both Pan-European- and ROW-destined exports and the share of capital intensive has remained roughly unchanged, expansion in exports of skilled labor intensive products to Pan-European markets and that of unskilled labor intensive to ROW markets has driven the convergence. The latter trend, however, has begun to subside in 2002, with skilled labor intensive products recording the strongest growth in exports to both ROW and Pan-European countries in 2002-04.

\section{E. Conclusions}

In a nutshell, the picture of Turkey's industrial development that emerges from the analysis through the lenses of the level of technology and factor content of foreign trade testifies to the emergence of modern industrial structures highly competitive in global and pan-European markets. Over the last five years, there has been a very pronounced shift towards production of goods requiring skilled labor and more sophisticated technologies. The shift is comparable in scope to that incurred by the EU-8 economies during the pre-accession period. Its major levers in both cases have been skilled labor and capital intensive products manufactured in operations characterized by medium to high technology.

Although low technology and unskilled labor intensive products together with resourcebased products still account for more than half of Turkish exports to Pan-European preferential partners, exports of medium to high technology products with high content of capital and skilled labor were the levers of the recent export expansion. If the average rates of export growth recorded in 2000-03 were sustained, the aggregate share of skilled labor and capital intensive products in total exports would exceed the 50 percent threshold in 2007.

The shift towards products requiring more capital, better-trained labor force and more sophisticated technologies has two important consequences. First, industries intensive in skilled labor and capital tend to pay higher wages. It seems that the growth of exports in these sectors has boosted output growth and helped improve living standards. In contrast, exports of natural resource-based products that involve little processing do not have the similar effect on wages.

Second, the shift away from products embodying natural resources and unskilled labor competitive in global markets augurs well for future sustainability of exports. High wages in higher technology sectors lead also to higher wages in services (especially in non-tradables) and unskilled labor-intensive sectors, such as textiles and footwear. Given the growing competition from low-wage countries in Asia and elsewhere, these exports may not be sustainable over a longer term. On the other hand, capital and skilled labor intensive products are less sensitive to changes in labor cost. Sustainability of their exports hinges critically on the availability of high quality human capital and firms’ absorptive capacity of new technologies.

\footnotetext{
${ }^{13}$ Another way of expressing the differences is sum of absolute differences between shares. This fell from an average of around of 45 in 1991-96 to 27 in 1999 and 18 percentage points in 2004.
} 
Capital and labor have been moving to more sophisticated and higher value added activities and more processed goods with higher content of capital and skilled labor have been expanding faster than traditional inputs and unskilled labor intensive products.

\section{Integration into EU production structures: participation in EU-driven value chains and networks}

The emergence of international production and distribution networks has triggered globalization of economic activities and revamped the economic landscape facing nations, industries and individual firms. Such networks, also known as commodity chains, refer to the whole range of activities involved in the design, production and marketing of a product. Its trademark is dividing up the value chain into smaller components and moving them to countries where their costs of production could be lower. One may distinguish between 'buyer-driven' and 'producer-driven' value chains (Gereffi, 1999, p.41-42). The former refers to the case of global buyers creating a supply-base upon which production and distribution systems are built without direct ownership. We include in it textiles and clothing (TC), footwear and furniture. The 'producer-driven' networks refer to vertically integrated arrangements as exemplified by automotive networks, information, and communication technology networks.

Network trade has been also the driving force of EU-8 economies' integration into global markets. The most developed of them have moved through two stages. First, 'buyer-driven' network exports have been the first major vehicle linking them to external markets. The point of departure has been as a rule inward processing in relatively technologically simple and capital non-intensive activities such as clothing often followed and/or accompanied in transition economies by footwear and furniture. The second stage has been participation in 'producerdriven' networks. Engagement in global networks in electronics or automotive industry usually comes at higher stages of economic development. It marks moving to a new division of labor based on production fragmentation.

Integration into EU-25 production and distribution value chains and networks structures has been the driver of Turkey's increasing participation in division of labor based on outsourcing and production fragmentation. EU-25 absorbed 68 percent (together with other Pan-European countries 72 percent) of all Turkish network exports as compared to 56 percent of Turkish total exports (Table 15). Network exports to the EU have expanded rapidly, with their share in total EU-25-destined exports rising from 58 percent on average in 1995-99 to 62 percent in 2004. Furthermore, the share of markets other than the Pan-European free trade area for industrial products has been declining pointing to closer links of Turkish firms with multinationals operating out of the EU-25.

Table 15: Significance of Pan-European markets in Turkish all network trade in 1995-99 and 2000-04 and 2004 (in percent)

\begin{tabular}{|c|c|c|c|c|c|c|c|c|c|}
\hline \multirow[b]{2}{*}{ Market } & \multicolumn{3}{|c|}{$\begin{array}{l}\text { Average share in Turkey's } \\
\text { total networks' exports }\end{array}$} & \multicolumn{3}{|c|}{$\begin{array}{l}\text { Average share in Turkey's } \\
\text { all goods exports }\end{array}$} & \multicolumn{3}{|c|}{$\begin{array}{l}\text { Share of total network exports in } \\
\text { all goods exports to }\end{array}$} \\
\hline & 1995-99 & 2000-04 & 2004 & 1995-99 & $2000-04$ & 2004 & 1995-99 & $2000-04$ & 2004 \\
\hline EU-25 & 66.2 & 68.0 & 69.5 & 53.7 & 55.1 & 55.3 & 57.9 & 61.6 & 61.8 \\
\hline Other Pan-Euro & 3.2 & 3.2 & 3.9 & 3.6 & 3.8 & 4.4 & 41.8 & 42.1 & 43.7 \\
\hline ROW & 30.6 & 28.8 & 26.6 & 42.7 & 41.1 & 40.3 & 33.7 & 35.0 & 32.5 \\
\hline
\end{tabular}

Note: Total networks include T\&C, footwear, furniture, automobile and ICT chains.

Source: Computations based on Turkey data from UN COMTRADE Statistics.

Network trade, accounting now for almost three-thirds of Turkey’s EU-destined exports, has also driven Turkey's integration into EU markets in a pattern and sequence similar to that observed earlier in several EU-8 economies. While Turkey has not as yet moved fully to the second stage, the process appears to be at a full swing. The value of exports of parts and final 
products from 'producer-driven' networks increased 178 percent in 2000-04, while those from 'buyer-driven' networks increased by a very respectable 50 percent. As a result, the composition of network exports has been undergoing significant evolution, with their share in all networks' exports increasing from 11 percent in 1990-96 to 23 percent in 2000 and 38 percent in 2004.

This section examines in more detail Turkey's place in evolving division of labor driven regionally by EU Eastern Enlargement Project. It assesses participation of Turkish firms in global chains organized around the EU-15 but also increasingly encompassing some recent EU entrants, mainly Hungary and to a lesser extent the Czech Republic that are becoming regional intermediaries in 'producer-driven' networks (Kaminski 2005).

\section{A. Participation in 'buyer-driven' value chains in comparative perspective}

'Buyer-driven' commodity chains tend to exist in industries in which large retailers, branded marketers and branded manufacturers play the pivotal roles in setting up decentralized production networks in a variety of exporting countries, typically in developing or transition economies. This pattern has become common in labor-intensive, consumer goods sectors, such as apparel, footwear, etc. Our focus will be on three 'buyer-driven' chains: textiles and clothing (T\&C); footwear; and furniture. The latter differs especially from T\&C value chains, as it involves operations that tend to be more diversified and complex requiring larger local input of skills and investment in capital assets. Similarly to clothing and footwear, furniture producers operating in a global value chain supply products according to specification provided by large multinational retailers. They also tend to be locally owned, albeit not always, ${ }^{14}$ but the relationship between supplier and multinational retailer frequently reflects larger complexity of tasks involved. In consequence, their relationship is based on a more long-term mutual commitment, which is less sensitive to the rise in labor costs and creates more opportunities for spillovers.

Clothing and, to a lesser extent, footwear and furniture have been the quintessential engines of growth for many EU-8 and other European economies during the initial stages of transition. They have accounted for a significant share of value added and manufacturing employment, with consequential implications for poverty reduction. With increasing wages in successful reformers, many of outward processing operations in the clothing sector have been shifting to economies less advanced in the transformation process to take advantage of lower labor costs in other countries in Central and South East Europe through the 1990s. The dates when their share in exports of manufactures peaked indicates the end of T\&C as engines of export growth. In contrast to Bulgaria and Romania as well as other SEE-4 economies, where T\&C shares peaked only in the second half of the 1990s and early 2000s, Turkey followed the pattern of EU-8, with their share peaking in the early 1990s (Table 16).

Despite a similar time profile, the share of T\&C products in Turkish exports peaked at a much higher level than in the EU-8 economies and consequently still accounts-despite a very significant contraction of 16 percentage points - for a much larger share of the total export than in EU-8 exports. It is lower, however, than in exports originating in Bulgaria and Romania. Exports from these two countries had positive growth rates in 1995-04. Neither Turkey nor any EU-8 had positive growth rates of T\&C exports during this period. Among EU-8 economies Latvia has the largest share of T\&C chain products in its total exports.

\footnotetext{
${ }^{14}$ Turkey and Romania stand out. Firms with foreign capital are present in Turkey's clothing industries. For instance, four firms specializing in wearing apparel (excluding knit) account for 89 percent of total capital stock of this sector and 212 firms producing ready made garments account for 71 percent (MIT 2004, p. 46). Foreign-owned firms, mainly Italian, tower the Romanian apparel and garment sector (Kaminski and Ng 2004).
} 
Table 16: Shift away from clothing global value chain of EU-8 and share of clothing in exports of manufactured goods excluding chemicals and 'buyer-driven' exports in 1992-2004 (in percent)

\begin{tabular}{|c|c|c|c|c|c|c|c|c|c|}
\hline \multirow[t]{2}{*}{ Country } & \multirow[t]{2}{*}{$\begin{array}{l}\text { Peak } \\
\text { Year }\end{array}$} & \multirow{2}{*}{\begin{tabular}{|c|} 
Share in \\
Peak Year \\
$(\%)$
\end{tabular}} & \multirow{2}{*}{$\begin{array}{c}\text { Percent } \\
\text { Share in } \\
2004\end{array}$} & \multirow{2}{*}{$\begin{array}{l}\text { Exports (\$ } \\
\text { million) } \\
2004\end{array}$} & \multirow[t]{2}{*}{\begin{tabular}{|l|} 
Index: 2004 \\
Peak=100
\end{tabular}} & \multirow{2}{*}{$\begin{array}{c}\text { Least Square } \\
\text { Growth (\%) } \\
1995-04\end{array}$} & \multicolumn{3}{|c|}{$\begin{array}{l}\text { Share of T\&C in 'buyer- } \\
\text { driven' chains' exports in }\end{array}$} \\
\hline & & & & & & & 1995 & 2004 & $\%$ point ch. \\
\hline EU-8 & & & & & & & & & \\
\hline Czech R. & 1993 & 7.4 & 2.0 & 858 & 26 & -11.1 & 70.7 & 64.3 & -6.4 \\
\hline Estonia & 1993 & 27.5 & 7.0 & 279 & 25 & -10.5 & 76.2 & 56.3 & -19.9 \\
\hline Hungary & 1992 & 20.8 & 3.1 & 1,134 & 15 & -15.8 & 71.0 & 64.5 & -6.5 \\
\hline Latvia & 1994 & 22.7 & 14.6 & 271 & 64 & -1.5 & 83.9 & 72.0 & -12.0 \\
\hline Lithuania & 1999 & 34.8 & 19.3 & 678 & 56 & -4.0 & 88.6 & 64.8 & -23.8 \\
\hline Poland & 1993 & 21.4 & 4.3 & 1,834 & 20 & -15.4 & 65.6 & 38.3 & -27.2 \\
\hline Slovak R. & 1994 & 8.9 & 3.3 & 668 & 37 & -8.7 & 69.3 & 54.4 & -15.0 \\
\hline $\begin{array}{l}\text { Slovenia } \\
\text { SEE-4 }\end{array}$ & 1992 & 15.6 & 3.7 & 368 & 24 & -12.2 & 62.7 & 41.0 & -21.6 \\
\hline Albania & 2000 & 41.5 & 34.0 & 143 & 82 & -1.6 & 57.6 & 45.7 & -11.9 \\
\hline $\mathrm{BiH}$ & 1998 & 28.5 & 16.1 & 153 & 56 & 0.7 & 44.9 & 36.2 & -8.6 \\
\hline FYROM & 2003 & 47.9 & 40.1 & 408 & 84 & 1.4 & 88.1 & 88.7 & 0.6 \\
\hline $\begin{array}{l}S \text { and } M \\
\text { EU-candidates }\end{array}$ & 1992 & 22.4 & 11.2 & 207 & 50 & 7.7 & 59.8 & 58.7 & -1.1 \\
\hline Bulgaria & 2001 & 37.7 & 31.2 & 1,616 & 83 & 5.1 & 82.6 & 80.9 & -1.7 \\
\hline Croatia & 1993 & 32.3 & 17.1 & 613 & 53 & -5.7 & 67.6 & 64.6 & -3.0 \\
\hline Romania & 1999 & 37.1 & 29.5 & 5,276 & 80 & 0.7 & 64.0 & 66.2 & 2.2 \\
\hline Turkey & 1992 & 46.9 & 27.2 & 12,057 & 58 & -4.2 & 98.3 & 95.4 & -2.9 \\
\hline
\end{tabular}

Note: Manufactured goods excluding chemicals

Source: Computations based on world import data from UN COMTRADE Statistics.

A feature setting Turkey aside from EU-8 firms' involvement in 'buyer-driven' value chains is a relatively much smaller presence of furniture chains in exports of 'buyer-driven' chains. The value of their exports of US\$ 180 million was about half of exports of furniture network and one-tenth of T\&C exports (Table 17). In contrast to most EU-8, the T\&C chain towers over other buyer-driven' value chain with the share in total 'buyer-driven' chains' exports at 96 percent in 2003. Except for Macedonia, the dominance of T\&C chain is much less pointed in exports from other countries.

Yet, Turkey appears to be moving along the same path that the EU-8 economies took earlier, with its furniture sector rapidly becoming integrated into international supply chains. Although the share of furniture network's products in exports of manufactured goods (excluding chemicals) remains well below the levels in other transition pan-European countries, ${ }^{15}$ there are some signs of change in EU-25-destined exports. The contraction, admittedly very small, in the share of T\&C products in total exports of 'buyer-driven' chains from 99 percent in 2000 to 96 percent in 2003 has been only because of the emergence of the furniture network as a significant exporter (Table 17). The value of exports of furniture network reached US\$ 456 million in 2003, with its share in total 'buyer-driven' exports almost quadrupling from 0.8 percent in 1995 to 2.9 percent in 2000 and further rising to 2.5 percent in 2003 and 3.3 percent in 2004.

\footnotetext{
${ }^{15}$ The lowest share among EU-8 was 2 percent (Hungary) as compared to Turkey's 1.5 percent. This share was the highest in Lithuania's exports (13.4 percent) followed by Poland (11 percent), Estonia (10 percent) and Latvia (9 percent). In both Bulgarian and Romanian, the share was higher than in Turkey's exports and amounted in 2003 to 3.4 percent and 5.5 percent respectively.
} 
Table 17: Characteristics of 'buyer-driven' chains in terms of exports and imports in 1995, 2000 and 2004 (in percent and million of US dollars)

\begin{tabular}{|c|rrr|rrr|rrr|}
\hline & \multicolumn{4}{|l|}{ T\&C chain } & Footwear chain & \multicolumn{3}{|c|}{ Furniture network } \\
\hline & 1995 & 2000 & 2004 & 1995 & 2000 & 2004 & 1995 & 2000 & 2004 \\
\hline \hline Network exports (US\$ mill) & 8,650 & 10,223 & 17,662 & 114 & 114 & 205 & 75 & 179 & 611 \\
share in total 'buyer-driven' & 97.9 & 97.2 & 95.6 & 1.3 & 1.1 & 1.1 & 0.8 & 1.7 & 3.3 \\
\hline Exports of parts (US\$ mill.) & 2,525 & 3,672 & 6,429 & 1 & 13 & 23 & 18 & 38 & 129 \\
share in total 'buyer-driven' & 99.2 & 98.6 & 97.7 & 0.1 & 0.4 & 0.3 & 0.7 & 1.0 & 2.0 \\
\hline Network imports (US\$ mill) & 1,924 & 2,469 & 5,005 & 46 & 114 & 303 & 73 & 201 & 296 \\
share in total 'buyer-driven' & 94.2 & 88.7 & 89.3 & 2.2 & 4.1 & 5.4 & 3.6 & 7.2 & 5.3 \\
\hline Imports of parts (US\$ mill.) & 1,833 & 2,150 & 4,226 & 12 & 12 & 16 & 27 & 59 & 154 \\
share in total 'buyer-driven' & 97.9 & 96.8 & 96.1 & 0.6 & 0.5 & 0.4 & 1.4 & 2.7 & 3.5 \\
\hline
\end{tabular}

Source: Computations based on UN COMTRADE Statistics.

Export growth rates of each network exceeded the growth of the EU's external import demand for these products. As a result, producers in 'buyer-driven' networks have succeeded in increasing their share in EU external imports through the combination of increases of exports of both parts and final products. Suppliers of footwear had the largest increase but from a very small base. Turkish T\&C chain accounting now for around 15 percent of EU imports of textiles and clothing has also seen a substantial, 25 percent increase in its share in 2000-03. The presence of furniture network in EU markets is also visible, as suppliers of furniture parts account for more than 5 percent of these EU external imports (Table 18).

It appears that Turkish firms operating in 'buyer-driven' chains are not merely assembly shops for EU multinationals taking advantage of cheap labor. While without the survey of firms in sectors or access to input-output tables it would be impossible to provide an unequivocal proof of this assertion, an examination of trade data tabulated in Table 18 suggests a two-way involvement going beyond simple outward processing.

In fact, trade flows, encompassing two-way movements of both parts and final products within each chain point to the development of backward linkages. Import intensities in each chain, i.e., imports of parts/inputs relative to exports of final products and parts, have been declining. This indicates increase in local content, with parts domestically produced replacing imports. It appears that domestic suppliers of the T\&C network were in business in 1996, as the import content of inputs in T\&C exports was already very low then. Import intensity of T\&C exports has remained at a low level of around 20 percent. ${ }^{16}$ The import intensity of footwear and parts is relatively low. It fell from 13 percent in 1996 to 7 percent in 2001 and then increased to 10 percent in 2004. In contrast, the import intensity of total furniture network exports fell between 1996 (50 percent) and 2003 (19 percent), but it rose to 34 percent in 2004. This ratio has been remarkably stable in the T\&C chain. Its low level suggests a high value added domestically to its exports. While no firm conclusions can be drawn on the basis of such a crude measure, part of it can be attributable to more developed backward linkages in the Turkish T\&C chains.

Another feature shared by all networks except footwear, but only in 2003, is that they are net exporters. Exports from T\&C network were consistently around four times higher than their imports in 1996-2003 and rose to more than six times higher in 2004. Except for furniture, other sectors increased their respective positive trade balances. The ratio of exports to imports for the furniture sector fell from 250 in 2003 to 161 percent in 2004.

\footnotetext{
${ }^{16}$ Its import intensity of 23 percent is much lower than the same ratio for Bulgaria's TC chain of 55 percent. Although the higher level may be due to imported fabrics being used for producing more processed fabrics for exports, this probably does not explain the whole difference.
} 
Table 18: Trade with the EU-25 in 'buyer-driven' chains in 1996, 200-2004

\begin{tabular}{|c|c|c|c|c|c|c|c|}
\hline Product (SITC Rev. 2) & 1996 & 2000 & 2001 & 2002 & 2003 & 2004 & $\begin{array}{r}\text { Index } 2004 \\
2000=100 \\
\end{array}$ \\
\hline \multicolumn{8}{|l|}{ Textile \& Clothing (SITC 65+8998+84) } \\
\hline Total exports of T\&C (\$ mill.) & 6,144 & 6,807 & 7,098 & 8,036 & 10,090 & 11,542 & 170 \\
\hline Share of Textiles in total T\&C (\%) & 23.6 & 29.4 & 30.7 & 26.7 & 26.5 & 27.2 & 92 \\
\hline Imports of textiles (\$ mill.) & 1,012 & 1,182 & 1,093 & 1,402 & 1,612 & 1806 & 153 \\
\hline $\begin{array}{l}\text { Share of textiles in T\&C imports (\%) } \\
\text { Memo Items: }\end{array}$ & 84.8 & 83.4 & 85.0 & 85.7 & 83.2 & 84.2 & 101 \\
\hline Share of T\&C in Turkey's all exports (\%) & 50.3 & 44.7 & 41.6 & 41.1 & 38.5 & 33.1 & 74 \\
\hline Share of EU25 in Turkey's total T\&C exports (\%) & 69.8 & 66.6 & 66.8 & 65.2 & 66.1 & 65.4 & 98 \\
\hline Share of EU15 in Turkey's total T\&C exports (\%) & 66.2 & 64.9 & 64.8 & 63.0 & 64.0 & 62.8 & 97 \\
\hline Share in EU25 external imports of T\&C (\%) & 11.1 & 11.7 & 12.4 & 13.6 & 14.6 & 14.8 & 127 \\
\hline of which: Textiles (\%) & 8.8 & 11.7 & 13.2 & 13.5 & 15.0 & 15.7 & 134 \\
\hline Clothing (\%) & 12.1 & 11.8 & 12.2 & 13.8 & 14.6 & 14.5 & 124 \\
\hline Total imports of textiles in $\%$ of total exports & 22.3 & 21.0 & 18.3 & 23.4 & 22.9 & 13.2 & 91 \\
\hline Total exports in \% of total imports & 404 & 414 & 475 & 380 & 379 & 639 & 111 \\
\hline \multicolumn{8}{|l|}{ Footwear and Parts (SITC 85+6123) } \\
\hline Total exports of footwear \& parts (\$ mill.) & 39 & 36 & 42 & 52 & 83 & 106 & 298 \\
\hline Share of parts in total footwear \& parts exports & 1.1 & 3.9 & 2.5 & 3.6 & 3.4 & 4.6 & 118 \\
\hline Imports of footwear \& parts (\$ mill.) & 61 & 63 & 44 & 53 & 64 & 74 & 118 \\
\hline $\begin{array}{l}\text { Share of parts in footwear \& parts imports } \\
\text { Memo Items: }\end{array}$ & 22.4 & 17.7 & 18.7 & 19.5 & 19.2 & 14.9 & 84 \\
\hline Share of footwear \& parts in Turkey's all exports & 0.3 & 0.2 & 0.2 & 0.3 & 0.3 & 0.3 & 130 \\
\hline Share of EU25 in Turkey's total footwear exports & 26.1 & 31.3 & 33.0 & 39.5 & 45.2 & 51.7 & 165 \\
\hline Share of EU15 in Turkey's total footwear exports & 12.3 & 19.7 & 21.9 & 29.4 & 36.1 & 43.7 & 222 \\
\hline Share in EU25 external imports of footwear \& parts (\%) & 0.26 & 0.27 & 0.36 & 0.53 & 0.70 & 0.71 & 259 \\
\hline of which: Parts (\%) & 0.03 & 0.14 & 0.17 & 0.17 & 0.25 & 0.31 & 216 \\
\hline Footwear, final goods (\%) & 0.30 & 0.29 & 0.40 & 0.58 & 0.76 & 0.75 & 258 \\
\hline Total imports of parts as \% of total exports & 13.3 & 10.4 & 6.9 & 9.2 & 8.6 & 10.4 & 33 \\
\hline Total exports in \% of total imports & 154 & 100 & 150 & 113 & 96 & 143 & 252 \\
\hline \multicolumn{8}{|l|}{ Furniture and Parts Network } \\
\hline Total exports of furniture $\&$ parts ( $\$$ mill.) & 33 & 103 & 119 & 162 & 257 & 343 & 334 \\
\hline Share of parts in total furniture network exports & 35.5 & 21.1 & 19.8 & 21.0 & 22.8 & 22.1 & 105 \\
\hline Imports of furniture \& parts (\$ mill.) & 114 & 159 & 103 & 112 & 142 & 213 & 138 \\
\hline $\begin{array}{l}\text { Share of parts in total furniture network imports } \\
\text { Memo Items: }\end{array}$ & 29.1 & 29.7 & 33.2 & 45.0 & 46.9 & 54.1 & 177 \\
\hline Share of furniture \& parts in Turkey's all exports & 0.3 & 0.7 & 0.7 & 0.8 & 1.0 & 1.0 & 146 \\
\hline Share of EU25 in Turkey's total furniture exports & 41.1 & 57.0 & 59.5 & 55.9 & 56.2 & 56.1 & 98 \\
\hline Share of EU15 in Turkey's total furniture exports & 38.6 & 53.3 & 57.8 & 53.6 & 53.3 & 52.7 & 99 \\
\hline Share in EU25 external imports of furniture \& parts (\%) & 2.10 & 2.60 & 3.17 & 3.86 & 4.25 & 4.4 & 162 \\
\hline of which: Parts (\%) & 4.76 & 4.59 & 5.25 & 6.26 & 6.48 & 6.5 & 141 \\
\hline Furniture, final goods (\%) & 0.94 & 1.76 & 2.26 & 2.82 & 3.31 & 3.5 & 188 \\
\hline Total imports of parts as $\%$ of total exports & 50 & 33 & 20 & 20 & 19 & 34 & 73 \\
\hline Total exports in \% of total imports & 59 & 89 & 162 & 223 & 250 & 161 & 242 \\
\hline \multicolumn{8}{|l|}{ Total Buyer-Driven Chains } \\
\hline Share of total above chains in Turkey's all exports (\%) & 50.9 & 45.6 & 42.6 & 42.2 & 39.8 & 34.4 & 75 \\
\hline Share of EU25 in Turkey's total above chain exports (\%) & 68.8 & 66.0 & 66.3 & 64.7 & 65.6 & 64.9 & 98 \\
\hline Share of EU15 in Turkey's total above chain exports (\%) & 65.0 & 64.2 & 64.2 & 62.5 & 63.3 & 62.3 & 97 \\
\hline Share in EU25 external imports of total above chains (\%) & 9.4 & 9.6 & 10.2 & 11.2 & 11.9 & 120 & 124 \\
\hline of which: Parts & 8.0 & 10.3 & 11.5 & 11.8 & 12.9 & 13.5 & 131 \\
\hline \begin{tabular}{|c} 
Final products \\
\end{tabular} & 9.9 & 9.5 & 9.8 & 11.0 & 11.7 & 11.6 & 123 \\
\hline
\end{tabular}

Source: Computations based on UN COMTRADE Statistics.

Links to Pan-European consumers and suppliers of parts for further processing in Turkey have expanded since 1995 in most networks. Except for the T\&C network, Pan-European markets absorbed over 1995-2003 a growing share of network exports and Pan-European producers accounted for an increasing share of imported inputs (Table 19). In 2004, these trends were reversed, as trade with the rest-of-world expanded slightly faster than with pan-European countries. 
Table 19: Direction of trade in 'buyer-driven' network products and parts in 1995, 2000 and 2004 (in percent)

\begin{tabular}{|c|c|c|c|c|c|c|c|c|c|}
\hline & \multicolumn{3}{|l|}{ EU-25 } & \multicolumn{3}{|c|}{ Other Pan-Euro } & \multicolumn{3}{|l|}{ ROW } \\
\hline & 1995 & 2000 & 2004 & 1995 & 2000 & 2004 & 1995 & 2000 & 2004 \\
\hline \multicolumn{10}{|l|}{ T\&C network } \\
\hline $\begin{array}{l}\text { Total exports } \\
\text { Imports of textiles }\end{array}$ & $\begin{array}{l}70.1 \\
33.6\end{array}$ & $\begin{array}{l}66.6 \\
47.9\end{array}$ & $\begin{array}{l}65.4 \\
36.0\end{array}$ & $\begin{array}{l}2.6 \\
2.9 \\
\end{array}$ & $\begin{array}{l}2.8 \\
2.5 \\
\end{array}$ & $\begin{array}{l}3.7 \\
2.6 \\
\end{array}$ & $\begin{array}{l}27.3 \\
65.2\end{array}$ & $\begin{array}{l}30.6 \\
51.5\end{array}$ & $\begin{array}{l}30.9 \\
61.4 \\
\end{array}$ \\
\hline \multicolumn{10}{|l|}{ Footwear network } \\
\hline $\begin{array}{l}\text { Total exports } \\
\text { Imports of parts }\end{array}$ & $\begin{array}{l}40.7 \\
41.2\end{array}$ & $\begin{array}{l}31.3 \\
94.0\end{array}$ & $\begin{array}{l}51.7 \\
68.7\end{array}$ & $\begin{array}{c}6.5 \\
51.7 \\
\end{array}$ & $\begin{array}{l}2.6 \\
5.3 \\
\end{array}$ & $\begin{array}{c}8.3 \\
0.32 \\
\end{array}$ & $\begin{array}{l}52.9 \\
58.8\end{array}$ & $\begin{array}{c}66.1 \\
5.9\end{array}$ & $\begin{array}{l}40.0 \\
31.0\end{array}$ \\
\hline \multicolumn{10}{|l|}{ Furniture network } \\
\hline $\begin{array}{l}\text { Total exports } \\
\text { Imports of parts }\end{array}$ & $\begin{array}{l}39.3 \\
75.3\end{array}$ & $\begin{array}{l}57.2 \\
80.0\end{array}$ & $\begin{array}{l}56.1 \\
75.0\end{array}$ & $\begin{array}{l}3.5 \\
1.0\end{array}$ & $\begin{array}{l}3.5 \\
0.5\end{array}$ & $\begin{array}{l}4.3 \\
1.0\end{array}$ & $\begin{array}{l}57.2 \\
23.7\end{array}$ & $\begin{array}{l}39.2 \\
19.5\end{array}$ & $\begin{array}{l}39.6 \\
24.0\end{array}$ \\
\hline
\end{tabular}

Source: Computations based on Turkey reporting to UN COMTRADE Statistics.

In all, developments in trade of 'buyer-driven' value chains seem to support the following observations: Respective industrial sectors in Turkey are not enclaves, but appear to be soundly immersed in the domestic economy. Each of them has been competitive in Pan-European markets registering gains in market shares consistently and without reversals over time, which, in turn, indicates continuous industrial modernization. These sectors have become parts of global value chains, organized mainly by EU firms, as trade with the EU and other Pan-European partners accounts for more than half of Turkey's total trade turnover. Furthermore, although T\&C towers over other sectors involved in 'buyer-driven' chains, furniture network has recently displayed strong growth outperforming in terms of exports other chains.

\section{B. 'Producer-driven' chains: automotive and information technology networks}

Production fragmentation in vertically integrated sectors has led to the emergence of 'producer-driven' network trade. It differs in several important respects from traditional, 'buyerdriven' global value chains. It includes two-way flows of parts and components across firms located in various countries for further processing and development occurring at several tiers with large multinational corporations playing a central role in coordinating the production process.

'Producer-driven' networks are mainly present in capital- and skilled-labor-intensive industries such as automobiles, computers, semiconductors and heavy machinery. Automotive and information and communication technology (ICT) represent the most dynamic 'producerdriven' networks. While outsourcing in clothing, footwear or furniture has rarely been accompanied by significant inflows of FDI, although there have been exceptions, the entry into supply chains of automotive and ICT networks is almost inconceivable without MNCs bringing capital, technology and marketing, albeit there are exceptions to this rule. ${ }^{17}$ As MNCs drive trade in these two networks, it may be also referred to as "MNC-driven" network trade. ${ }^{18}$

Not surprisingly, linkages with EU firms have been driving 'producer-driven' network trade and they appear to be much stronger than in 'buyer-driven' trade with the EU accounting for a larger share of network trade. Other Pan-European countries' firms and consumers remain marginal, although their significance increased over 2000-04. Automotive sector is more EUconcentrated than the ICT industries. While EU markets take a larger share of total ICT network's exports than automotive network's exports, ICT firms are much more dependent on imports of final products in particular from ROW (Table 20).

\footnotetext{
${ }^{17}$ A good example is the development of automotive industry in South Korea.

18 The empirically observed positive correlation between multinational activity and intra-industry trade would also clearly point in this direction (Markusen 1998).
} 
Table 20: Direction of trade in 'producer-driven' networks in 1995, 2000 and 2004 (in percent)

\begin{tabular}{|c|c|c|c|c|c|c|c|c|c|}
\hline & \multicolumn{3}{|l|}{ EU-25 } & \multicolumn{3}{|c|}{ Other Pan-European } & \multicolumn{3}{|l|}{ ROW } \\
\hline & 1995 & 2000 & 2004 & 1995 & 2000 & 2004 & 1995 & 2000 & 2004 \\
\hline \multicolumn{10}{|c|}{ Automobile network } \\
\hline Network exports & 57.8 & 63.8 & 72.8 & 3.2 & 2.4 & 4.0 & 39.1 & 33.7 & 23.2 \\
\hline Exports of parts & 63.6 & 65.2 & 65.1 & 2.0 & 1.0 & 1.8 & 34.5 & 33.8 & 33.1 \\
\hline Network imports & 75.5 & 80.0 & 81.3 & 0.9 & 0.5 & 0.6 & 23.6 & 19.6 & 18.1 \\
\hline Imports of parts & 79.6 & 70.6 & 79.7 & 1.2 & 0.8 & 0.6 & 19.2 & 28.6 & 19.7 \\
\hline \multicolumn{10}{|l|}{ ICT network } \\
\hline Network exports & 78.0 & 81.3 & 87.2 & 5.4 & 1.9 & 4.4 & 16.6 & 16.8 & 8.4 \\
\hline Exports of parts & 36.1 & 28.7 & 49.1 & 16.4 & 0.8 & 2.8 & 47.5 & 70.5 & 48.1 \\
\hline Network imports & 56.9 & 68.5 & 48.0 & 0.8 & 0.3 & 0.2 & 42.3 & 31.3 & 51.7 \\
\hline Imports of parts & 59.4 & 63.1 & 54.0 & 0.7 & 0.5 & 0.2 & 40.0 & 36.5 & 45.9 \\
\hline
\end{tabular}

Source: Computations based on Turkey reporting to UN COMTRADE Statistics.

Turkish firms entered 'producer-driven' networks with a big bang in 2001 and 2002. In 2001 the value of exports of automotive networks surged 64 percent. So did the value of ICT exports but a year later in 2002 - it had the same increase. The surge in automotive exports raised their share in EU external imports 59 percent from 2.9 percent in 2000 to 4.6 percent in 2001. The expansion continued in 2002-2004, with the share growing to 5.5 percent in 2002 and 9 percent in 2004. The sudden explosion in ICT exports resulted in a 71 percent increase in their share in EU imports of these products from 0.7 percent in 2001 to 1.2 percent in 2002 (Table 21). The share of these two sectors in Turkey's total EU-destined exports increased from 14 percent in 2000 to 23 percent in 2003 and 27 percent in 2004.

Although final products were behind the sudden surge of exports of both networks indicating specialization in assembly operations in the last stage of production process, there seem to be significant differences between two sectors in their modes of integration into global networks. ICT activities appear to consist mainly of assembly operations for exports. The share of parts in total ICT imports increased pointing to their growing use in assembly operations destined for exports. Another indication of specialization in the last stage of production process is the relatively low level of exports of parts and components. This suggests that there are few firms involved in supply chains of EU-based multinationals.

In contrast, firms of the automotive network appear to display much wider specialization spanning across parts, components and assembly operations of motor vehicles. But the two sectors also vary greatly in terms of size and specialization profile. The automotive sector in terms of its exports is much larger than ICT. The former accounted for 20 percent of Turkish total exports in 2004 and 9 percent of EU external imports, whereas the latter contributed respectable 7 percent but accounted only for 1.2 percent of EU imports of ICT products. The boost in exports of the automotive sector came mainly from exports of motor vehicles indicating the expansion in assembly operations. Yet, exports of parts and components doubled in terms of value rising from US\$ 1,269 million (of which US\$ 704 million went to the EU-25) in 2000 to US\$ 2.5 billion with the EU taking US\$ 1.4 billion in 2003 and US\$ 2.7 billion with the EU purchasing US\$ 1.8 billion in 2004 . Exports of motor vehicles more than quadrupled over the same period increasing from US\$ 1.2 billion (US\$ 653 million to EU) to US\$ 5.3 billion (EU-25 took US\$ 2.9 billion) and US\$ 7 billion (the EU US\$ 5.4 billion) in respective years. In consequence, the share of parts in total automotive network exports fell from 52 percent in 2000 to 32 percent in 2003 and 28 percent in 2004. During the same period, the share of parts in ITC exports was at around 2 percent. In brief, the involvement of producers of automotive parts in international supply networks exceeds significantly that of producers in the ITC sector. 
Table 21: Exports to EU-25 of producer-driven networks in 1996, 2000-2004 (in million of US dollars and percent)

\begin{tabular}{|c|c|c|c|c|c|c|c|}
\hline Producer-Driven Network (SITC Rev. 2) & 1996 & 2000 & 2001 & 2002 & 2003 & 2004 & $\begin{array}{l}\text { Index } \\
2004 \\
2000=100 \\
\end{array}$ \\
\hline \multicolumn{8}{|l|}{ Automobile Network } \\
\hline Total exports of auto \& parts (\$ mill.) & 577 & 1,357 & 2,225 & 2,783 & 4,355 & 7,019 & 517 \\
\hline Share of parts in total auto network exports & 54.6 & 52.1 & 42.9 & 38.8 & 32.3 & 24.9 & 48 \\
\hline Imports of auto \& parts (\$ mill.) & 2,582 & 5,391 & 2,255 & 2,953 & 6,011 & 10,529 & 195 \\
\hline Share of parts in total auto network imports & 46.7 & 37.5 & 63.6 & 62.6 & 47.3 & 45.0 & 120 \\
\hline $\begin{array}{l}\text { Share of parts imports in total auto network exports } \\
\text { Memo Items: }\end{array}$ & 208.8 & 149.1 & 64.5 & 66.4 & 65.3 & 67.5 & 45 \\
\hline Share of auto \& parts in Turkey's all exports (\%) & 4.7 & 8.9 & 13.0 & 14.2 & 16.6 & 20.1 & 226 \\
\hline Share of EU25 in Turkey's total auto network exports & 53.1 & 63.8 & 70.5 & 68.4 & 70.2 & 72.8 & 114 \\
\hline Share in EU25 external imports of auto \& parts & 1.6 & 2.9 & 4.6 & 5.5 & 7.0 & 8.8 & 303 \\
\hline of which: Parts & 2.0 & 3.0 & 3.9 & 4.5 & 5.4 & 5.9 & 194 \\
\hline Auto, final goods (\%) & 1.2 & 2.8 & 5.4 & 6.5 & 8.3 & 11.2 & 402 \\
\hline \multicolumn{8}{|l|}{$\begin{array}{l}\text { Information, Communication and Technology } \\
\text { Network (ICT) }\end{array}$} \\
\hline Total exports of ICT network (\$ mill.) & 228 & 819 & 811 & 1,333 & 1,692 & 2,556 & 312 \\
\hline Share of parts in total ICT network exports (\%) & 6.4 & 2.2 & 3.9 & 1.8 & 2.7 & 2.2 & 97 \\
\hline Imports of ICT network (\$ mill.) & 1,212 & 3,780 & 1,822 & 2,032 & 2,298 & 2,979 & 79 \\
\hline Share of parts in total ICT network imports (\%) & 40.5 & 29.3 & 45.2 & 52.5 & 55.3 & 51.3 & 175 \\
\hline (\%) & 215.6 & 135.0 & 101.5 & 80.1 & 75.1 & 59.7 & 44 \\
\hline \multicolumn{8}{|l|}{ Memo Items: } \\
\hline Share of ICT network in Turkey's all exports & 1.9 & 5.4 & 4.8 & 6.8 & 6.5 & 7.3 & 136 \\
\hline Share of EU25 in Turkey's total ICT network exports & 69.8 & 81.3 & 77.4 & 83.5 & 85.5 & 87.2 & 107 \\
\hline Share in EU25 external imports of ICT network & 0.3 & 0.6 & 0.7 & 1.1 & 1.1 & 1.2 & 206 \\
\hline of which: Parts (\%) & 0.1 & 0.1 & 0.1 & 0.1 & 0.1 & 0.1 & 160 \\
\hline $\begin{array}{c}\mathrm{ICT}, \text { final goods (\%) } \\
\end{array}$ & 0.4 & 1.1 & 1.3 & 2.0 & 1.9 & 2.0 & 175 \\
\hline \multicolumn{8}{|l|}{ Total Producer-Driven Networks } \\
\hline Share of total above networks in Turkey's all exports & 6.6 & 14.3 & 17.8 & 21.1 & 23.1 & 27.4 & 192 \\
\hline Share of EU25 in total above network exports & 57.0 & 69.5 & 72.2 & 72.6 & 73.9 & 76.2 & 110 \\
\hline Share in EU25 external & 0.6 & 1.2 & 1.8 & 2.5 & 2.9 & 3.4 & 289 \\
\hline of which: Parts (\%) & 0.6 & 0.8 & 1.2 & 1.5 & 1.7 & 1.8 & 222 \\
\hline Final goods (\%) & 0.7 & 1.6 & 2.4 & 3.3 & 3.8 & 4.6 & 293 \\
\hline
\end{tabular}

Source: Computations based on UN COMTRADE Statistics.

Other features setting apart automotive from ICT network are, first, that there is a large number of local suppliers of automotive parts and components and, second, the network appears to be moving rapidly towards the status of a net exporter. Large increase in their exports notwithstanding, the surge in exports of final products failed to trigger similar growth in imports of parts and components. While the value of total exports of the automotive network increased 417 percent in 2000-04, imports of parts increased only 95 percent. Furthermore, the import intensity - as measured by the ratio of imports of parts to total automotive exports - of the automotive sectors has been falling rather steeply since 1996 and is lower than in the ICT network trade. ${ }^{19}$ In trade with the EU the ratio fell from 3.04 in 1996 to 1.49 in 2000 and 0.68 in 2004, while in total trade of this network from 1.35 in 1995 and 2000 to 0.62 in 2004 (Table 22). Overall, exports as a percentage of imports increased steeply from 32 percent in 2000 to 87 percent in 2003. In other words, while in the 1990s imported parts were used among others to

\footnotetext{
${ }^{19}$ Based on network trade intensities of EU-8 that successfully have entered into supply chains, the value of the share of imports of parts in network's exports of parts and final products below 100 percent suggests significant involvement in division of production based on fragmentation (Kaminski and Ng, 2005).
} 
assemble cars and trucks for protected domestic markets, the 2000s witnessed the emergence of firms producing parts both for exports and domestic consumption as well as cars destined for foreign markets.

Table 22: Total automobile and ICT network trade and share of markets other than PanEuropean free trade area in 1995, 2000 and 2004(in million of US dollars and percent)

\begin{tabular}{|l|rrr|rrr|}
\hline & \multicolumn{3}{|c|}{ Automobile Network } & \multicolumn{3}{c|}{ ICT Network } \\
\cline { 2 - 7 } Producer-Driven Network Product & 1995 & 2000 & 2004 & 1995 & 2000 & 2004 \\
\hline Total network exports (\$ million) & 954 & 2,125 & 9,641 & 255 & 1,008 & 2,930 \\
Share of ROW (other than Pan Euro area) & 39 & 34 & 23 & 17 & 17 & 8 \\
\hline Exports of network final products (\$ mill) & 439 & 1,041 & 6,950 & 239 & 944 & 2,817 \\
Share of ROW (other than Pan Euro area) & 44 & 34 & 19 & 14 & 13 & 7 \\
\hline Total network imports (\$ million) & 2,033 & 6,742 & 12,952 & 1,677 & 5,522 & 6,200 \\
Share of ROW (other than Pan Euro area) & 24 & 20 & 18 & 42 & 31 & 52 \\
\hline Imports of network parts (\$ million) & 1,289 & 2,863 & 5,943 & 646 & 1,753 & 2,830 \\
Share of ROW (other than Pan Euro area) & 19 & 29 & 20 & 40 & 36 & 46 \\
\hline Total Exports as \% of total Imports (\%) & 47 & 32 & 74 & 15 & 18 & 47 \\
Imports of parts as \% of total exports (\%) & 135 & 135 & 62 & 253 & 174 & 97 \\
\hline
\end{tabular}

Source: Computations based on Turkey's data reported to the UN COMTRADE Statistics.

Last but not least, as it was signaled earlier, there is a difference in geographical patterns of external interaction. Producers in ICT networks rely more on imported inputs from other than pan-European suppliers and their exports are more concentrated on pan-European markets. Respective shares in imports of parts of the ROW in 2003 were 36 percent for the ICT network and 20 percent for the automotive network and in exports of final products 9 percent and 23 percent respectively.

\section{Turkey's producer-driven network trade in regional perspective}

Among EU candidates, Turkey is the only country whose firms appear to participate in division of labor driven by production fragmentation. The level of their participation appears to be higher than of two of EU-8, Latvia and Lithuania. The share of 'producer-driven' network products in exports of manufactures as well as its pace of growth was much stronger than in those two countries (Table 23).

Table 23: Features of 'producer-driven' network trade of EU-8 and EU-candidates in 1995, 2000 and 2004 (in million of US dollars and percent)

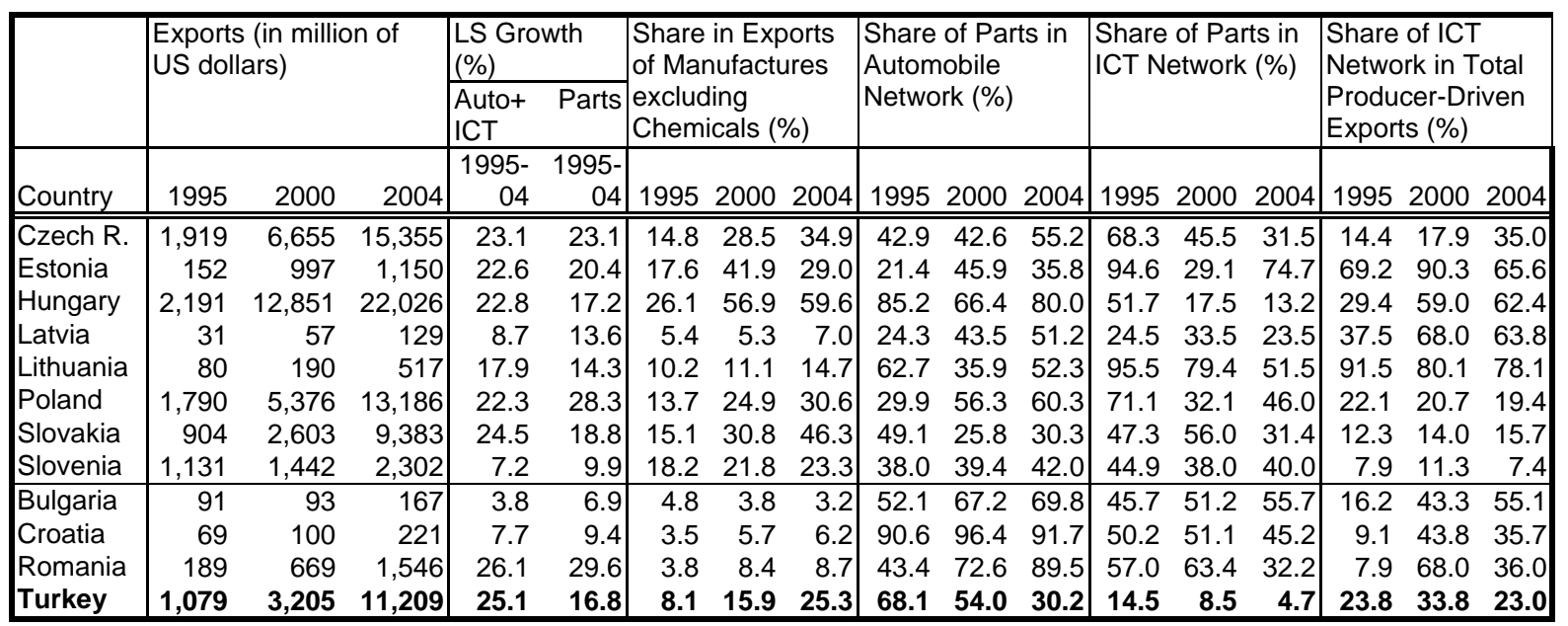

Source: Computations based on UN COMTRADE Statistics. 
Indeed, Turkey's performance stands out. Together with Hungary, Czech Republic, Slovak Republic, Slovenia, Estonia and Poland, Turkey has been identified in a recent World Bank study (WB 2006) as one of the seven "High Performers" among European and Central Asian countries in 'producer-driven' network trade. These countries share one major characteristic: the share of exports of 'producer-driven' networks in exports of manufactures, excluding chemicals, exceeded 20 percent in 2003. Turkey's share of 22.5 percent puts it on a par with Slovenia and well above levels in other EU candidate countries. Except for Slovenia, the most developed economy among EU-8, exports of parts and exports of final products in High Performers grew at average rates exceeding 15 percent per year in 1995-2003. As a result, the share of Turkey in total 'producer-driven' networks' exports of EU-8 and EU candidate countries increased from 9 percent in 2000 to 13 percent in 2003. This share in automotive exports is slightly higher amounting to 15 percent in 2003 up from 10 percent in 2000.

\section{Concluding observations}

While 'buyer-driven' network exports still accounted for 62 percent of all network exports in 2004, their share rather dramatically declined form almost 90 percent in 1995-97 and 75 percent in 2000. Moreover, the share of T\&C products in 'buyer-driven' network exports slightly fell because of the increased industrial activity within the furniture network.

Overall, there was a clear shift towards specialization in higher valued added 'producerdriven' networks. The value of their aggregate networks more than quadrupled increasing 340 percent while that of 'buyer-driven' exports increased 76 percent in 2004 over 2000. Exports of other parts and electro-engineering products more than doubled. The major driver of change, overall, has been automotive network, but strongly supported by the expansion in exports of ICT network final products.

The comparison with other High Performers in 'producer-driven' network trade in the region indicates the room for further expansion. Despite the impressive export performance over 2000-04, Turkey's total 'producer-driven' network exports were equivalent in 2004 of 51 percent of Hungary's exports, 73 percent of Czech, 85 percent of Poland's and 119 percent of Slovak exports.

\section{Conclusions}

Turkey's recent fast export expansion appears to be based on solid ground. It is geographically diversified; driven by skilled labor-intensive higher value added products with medium to high technology content; based on the entry of Turkish firms into supply chains of automotive and ICT networks; and supported by fast growth of unskilled labor and low techintensive products. The shift towards higher value added exports has been taking place because differentials in fast growth rates have been in their favor. This has not been due to either slow down or collapse of unskilled labor-intensive exports but to a stronger push in other exports.

The available evidence looks like an economic success story in the making, even if the story is far from over. Export expansion owes a lot to improved policy environment and domestic liberalization. It is rather telling that the recent expansion has coincided with the implementation of most provisions of the EU-Turkey Customs Union Agreement, the completion of the removal of tariffs on trade in industrial products among Pan-European parties to the Pan-European Cumulation of Origin Agreement and improved macroeconomic stability after the 2001 crisis. The Pan European Cumulation of Origin Agreement together with elimination of tariffs in the Pan-European area have set the groundwork for the growth of intra-industry and network trade.

The shift towards products requiring more capital, a better-trained labor force and more sophisticated technologies and participation in international 'producer-driven' networks has three important consequences. 
- First, industries intensive in skilled labor and capital tend to pay higher wages. It seems that the growth of exports in these sectors has boosted output growth and helped improve living standards. In contrast, exports of natural resource-based products that involve little processing do not have a similar effect on wages.

- $\quad$ Second, the shift away from products embodying natural resources and unskilled labor competitive in global markets augurs well for future sustainability of exports. High wages in higher technology sectors lead to higher wages in services (especially in non-tradables) and unskilled labor-intensive sectors, such as textiles and footwear. Given the growing competition from low-wage countries in Asia and elsewhere, these exports may not be sustainable over a longer term. On the other hand, capital and skilled labor intensive products are less sensitive to changes in labor cost. Sustainability of their exports hinges critically on availability of high quality human capital and firms' absorptive capacity of new technologies.

- Third, network members, albeit there is no lifetime, guaranteed membership, are less vulnerable to local shifts in demand as their 'centers' operate in multiple foreign markets. 


\section{References:}

Barysch, Katynka. 2005. The Economics of Turkish Accession, Centre for European Reform, London, June.

Blonigen, Bruce A. 2001. "In search of substitution between foreign production and exports" Journal of International Economics, 53: 81-104.

Gereffi, Gary. 1999. "International Trade and Industrial Upgrading in the Apparel Commodity Chain.” Journal of International Economics, 48: 37-70.

Kaminski, Bartlomiej. 2004. "Production Fragmentation and Trade Integration in Enlarged Europe: How MNCs have succeeded where CMEA had failed.” Papeles del Este: Transiciones poscommunistas. No. 9.

Kaminski, Bartlomiej and Francis Ng. 2004. "Romania's Integration into European Markets: Implications for Sustainability of the Current Export Boom." Policy Research Working Paper 3451, The World Bank, Development Research Group-Trade, Washington DC, May.

Landesmann, M. and R. Stehrer. 2003. "Structural Patterns of East-West European Integration: Strong and Weak Gershenkron Effects, in WIIW Structural Report 2003 on Central and Eastern Europe, Vol. 1, The Vienna Institute for International Economic Studies, Vienna.

Markusen, James R. 1998. "Multinational Firms, Location and Trade,” The World Economy. Vol. 21. No. 6. August (733-756).

Maurer, A. and P. Chauvet. 2002. "The Magnitude of Flows of Global Trade in Services,” in B. Hoekman, A. Mattoo, and Ph. English, eds., Development, Trade, and the WTO. A Handbook, The World Bank, Washington, D.C.

[MIT 2004] Turkey 2004: Economic and Industrial Outlook, Republic of Turkey, Ministry of Industry and Trade, Directorate General for European Union Co-ordination, Ankara, August.

Togan, Subidey, Husamettin Nebioglu and Saadettin Dogan. 2005. "Integration and Manufacturing Industry,” in Bernard Hoekman and Subidey Togan, eds. Turkey: Economic Reforms and Accession to the EU. The World Bank, Washington, D.C.

Togan, Subidey, 2004. “Turkey: Toward EU Accession,” The World Economy, vol. 27, no. 7, July, pp. 1013-45.

Togan, Subidey. 2000. "Effects of Turkey-European Union Customs Union and Prospects for the Future.” Russian and East European Finance and Trade, vol. 36, no. 4, July-August, pp. 5-25.

Togan, Subidey. 1997. "Opening up of the Turkish Economy in the Context of the Customs Union with the EU,” Journal of Economic Integration 12 (pp. 157-79).

[UNCTAD. 2002] World Investment Report: Transnational Corporations and Export Competitiveness. United Nations: New York and Geneva.

[World Bank 2006] From Disintegration to Integration: Europe and Central Asia in International Trade, preliminary draft, The World Bank, Washington, D.C. 